Review

\title{
Correlation between Oxidative Stress, Nutrition, and Cancer Initiation
}

\author{
Subbroto Kumar Saha, Soo Bin Lee, Jihye Won, Hye Yeon Choi, Kyeongseok Kim, \\ Gwang-Mo Yang, Ahmed Abdal Dayem and Ssang-goo Cho * ii
}

Department of Stem Cell and Regenerative Biotechnology, Incurable Disease Animal Model \& Stem Cell Institute (IDASI), Konkuk University, Seoul 05029, Korea; subbroto@konkuk.ac.kr (S.K.S.); soobineey@naver.com (S.B.L.); wjh021@naver.com (J.W.); hyeon.choi24@gmail.com (H.Y.C.); proproggs@naver.com (K.K.); slayersgod@nate.com (G.-M.Y.); ahmed_morsy86@yahoo.com (A.A.D.)

* Correspondence: ssangoo@konkuk.ac.kr; Tel.: +82-2-450-4207

Received: 30 May 2017; Accepted: 13 July 2017; Published: 17 July 2017

\begin{abstract}
Inadequate or excessive nutrient consumption leads to oxidative stress, which may disrupt oxidative homeostasis, activate a cascade of molecular pathways, and alter the metabolic status of various tissues. Several foods and consumption patterns have been associated with various cancers and approximately $30-35 \%$ of the cancer cases are correlated with overnutrition or malnutrition. However, several contradictory studies are available regarding the association between diet and cancer risk, which remains to be elucidated. Concurrently, oxidative stress is a crucial factor for cancer progression and therapy. Nutritional oxidative stress may be induced by an imbalance between antioxidant defense and pro-oxidant load due to inadequate or excess nutrient supply. Oxidative stress is a physiological state where high levels of reactive oxygen species (ROS) and free radicals are generated. Several signaling pathways associated with carcinogenesis can additionally control ROS generation and regulate ROS downstream mechanisms, which could have potential implications in anticancer research. Cancer initiation may be modulated by the nutrition-mediated elevation in ROS levels, which can stimulate cancer initiation by triggering DNA mutations, damage, and pro-oncogenic signaling. Therefore, in this review, we have provided an overview of the relationship between nutrition, oxidative stress, and cancer initiation, and evaluated the impact of nutrient-mediated regulation of antioxidant capability against cancer therapy.
\end{abstract}

Keywords: nutrition; oxidative stress; reactive oxygen species; cancer progression

\section{Introduction}

Nutrition is proposed to play an essential role in cancer progression. Cancer is the second leading cause of deaths in people from developed countries, whereas it is the most leading cause of death in people from developing or underdeveloped countries [1,2]. According to the International Agency for Research on Cancer (IARC), more than 10 million new cases and about 10 million fatal cases have occurred due to cancer onset worldwide [3]. In western countries, more than $65 \%$ of all the cancers occur upon exposure to numerous harmful substances, such as those present in western-style diet, alcohol, and smoking, that do not exist naturally in the environment [4].

Nutrition can also cause oxidative stress, augment a cascade of molecular reactions in cells, and alter the metabolic state of tissues [5]. Oxidative metabolism and redox homeostasis are suggested to be an essential part of aerobic life [6]. Living organisms cannot survive without these processes. Under such unfavorable conditions, oxygen derivatives can damage nucleic acids, lipids, and proteins; alter oxidative equilibrium; and regulate cell viability [7]. Oxidative stress induces the formation of excess antioxidants to protect the human body from antioxidant deficiency [8]. Moreover, nutrition can induce oxidative stress even in normal physiological conditions in the human body, and dietary 
factors can also serve as inflammatory and pro-oxidant factors [9]. Thus, nutritional oxidative stress might be described as a postprandial imbalance between the antioxidant defense and the pro-oxidant load as a consequence of inadequate or excess supply of nutrients [10].

Oxidative stress is known as a physiological state in which high levels of reactive oxygen species (ROS) and free radicals are generated due to antioxidant metabolism [11]. Normal cellular metabolism produces ROS and free radicals and plays a crucial role in cell signaling pathways [12]. Mechanically, mitochondria, the largest powerhouse of cells, generate ROS when generating adenosine triphosphate (ATP), whereby electrons react with oxygen $\left(\mathrm{O}_{2}\right)$ and subsequently form the superoxide anion $\left(\mathrm{O}_{2}{ }^{-}\right)$[13]. There are several studies confirming that oxidative stress may have a core relationship with human pathophysiological diseases [14-16]. Specifically, oxidative stress is prominently known to damage the DNA molecule, alter signaling pathways, and regulate progression of various cancers, including those of the breast, lung, liver, colon, prostate, ovary, and brain [17-23]. Moreover, it is reported that the whole DNA molecule can bind with hydroxyl radicals, and consequently, damage the deoxyribose backbone, including purine and pyrimidine bases. During these damaging processes, $8-\mathrm{OH}$ deoxyguanosine $(8-\mathrm{OHdG})$ can be produced, which may markedly increase the risk of mutagenesis [24]. The 8-OHdG molecules are also used as indicators to detect free radicals during DNA mutagenesis and are widely implicated as an early detection tool for cancer progression $[24,25]$. Importantly, 8-OHdG can transform GC pairs to TA pairs upon DNA replication, which might induce mutagenesis if oxidative lesions exist, subsequently causing cancer initiation [26].

The precise mechanisms underlying induction of oxidative stress by nutrition followed by cancer initiation are the current research topics, and the probable mechanisms include alterations in epigenetic events and induction of genomic instability, which alter gene expression, cause resistance to apoptosis, and induce tumor invasion and metastasis $[12,14-16,24,26]$. Therefore, in this review, we have provided an overview of the correlation between nutrition, oxidative stress, and carcinogenesis.

\section{Correlation between Nutrition and Oxidative Stress}

It is known that overnutrition may generate free radicals, and subsequently elevate oxidative stress [27] and ROS-mediated modulation of various molecular pathways [28-30]; therefore, scientists have directed increasing attention towards investigation of the function of oxidative stress in various pathophysiological diseases and normal body metabolism [16,31-35]. Therefore, the antioxidant capability of the human body is considered a crucial factor for overcoming free radical-mediated oxidative stress and the subsequent pathophysiological processes.

\subsection{Nutrition Induces Oxidative Stress during Early Human Development}

There are various crucial environmental factors, including nutrition, involved in epigenetic modifications [36]. For instance, undernutrition or malnutrition and low birth weight in utero due to early infant growth deficiency may be closely linked to risk factors, such as insulin resistance, obesity, reproductive dysregulation, and cardiovascular disease, in adulthood [37,38]. Similarly, offspring grown in a prenatally rich nutritional circumstance is at an increased risk of compromised fertility and cardiometabolic disorders later in life [39,40]. A recent study proposed that oxidative stress has a potent effect in nutrition-mediated epigenetic changes in various experimental models [41].

Obesity, maternal malnutrition, or obesogenic maternal diet upon gestation, but not in the post-weaning period [42], is associated with augmented oxidative stress markers and diminished antioxidant capability in the offspring, resulting in diabetogenic effects $[43,44]$. Concurrently, antioxidant supplementation could significantly attenuate obesity in their offspring [45]. Nutrition may trigger epigenetic changes in perinatal development into adulthood via different pathways, such as metabolic risk factor progression and oxidative stress generation. 


\subsection{Nutrition Triggers Oxidative Stress at the Cellular Level}

A previous study demonstrated that after glucose intake, mononuclear (MNC) and polymorphonuclear (PMN) leukocytes of normal subjects generate ROS and induce inflammation due to excess micronutrients [46]. Similarly, after lipid intake, leukocytes in normal subjects may also significantly induce ROS generation and inflammation; protein intake can trigger ROS generation, but to a much lesser degree than glucose and lipid intake can [47]. Moreover, upon assessing a mixed meal in well-fit subjects, severe inflammatory alterations were identified, with a reduction in inhibitor $k B \alpha$ $(\mathrm{I} \kappa \mathrm{B} \alpha)$, and upregulation of binding of nuclear factor $\kappa \mathrm{B}(\mathrm{NF}-\mathrm{\kappa B})$ and expression of inhibitory proteins p47 phox subunit, IKB kinase $\alpha$ (IKK $\alpha$ ), IкB kinase $\beta$ (IKK $\beta$ ), and plasma C-reactive protein (CRP) [48].

Postprandial oxidative stress might increase due to excessive caloric intake, which abnormally increases blood glucose, free fatty acids (FFA), and triglycerides circulating in the blood. These high concentrations of FFA and glucose outpace the entire capability of mitochondria for oxidative phosphorylation, ultimately leading to improved transfer from single electrons to molecular oxygen; consequently, $\mathrm{O}_{2}{ }^{-}$enters the circulation $[49,50]$. Besides mitochondria, $\mathrm{ROS}$ production by leukocytes is also induced by the caloric amount, as previous studies indicated that caloric limit led to a decent reduction in ROS production via lipid peroxidation and protein carboxylation [51-53].

Inappropriate lifestyle patterns of an individual, including physical inactivity or obesity, can also cause ROS production in the postprandial state. As a result, obese individuals experience pernicious and acute oxidative stress after a fatty meal, compared to responses of the non-obese well-fitted individuals [54]. Inconsistent data exist regarding the outcome of exercise in postprandial oxidative stress. Although exercise is thought as a tool to increase endogenous antioxidant defenses, numerous researchers have been unsuccessful in showing a positive effect of physical activity on postprandial oxidative stress [55-57].

Cooking method can also have a postprandial impact on oxidative metabolism. Protein- and fat-rich food cooked quickly under high temperatures lead to the formation of dietary advanced glycation end products (AGEs) [58]. Studies showed that a single oral challenge by AGEs (coke) caused severe postprandial endothelial dysfunction, as illustrated by a significant reduction in flow-mediated dilatation both in diabetic and in healthy subjects [59]. Nutritive AGEs appear to affect reproductively challenged women as well. A study in women with polycystic ovarian syndrome (PCOS) showed that low-AGE meals in combination with six-month treatment with orlistat (a lipase inhibitor) led to a significant improvement of their hormonal profile and body mass index (BMI) [60].

Taken together, increasing evidence demonstrates that nutrition triggers major oxidative and inflammatory imbalances in the postprandial state. Indeed, postprandial hyperlipidemia and hyperglycemia, or so-called postprandial dysfunction in the body, are gradually gaining vital consideration as major risk factors for some diseases. Continuous accumulation of all these imbalances during the constant postprandial state that symbolizes current lifestyles may contribute to the pathophysiology of reproductive and metabolic disorders (Figure 1). 


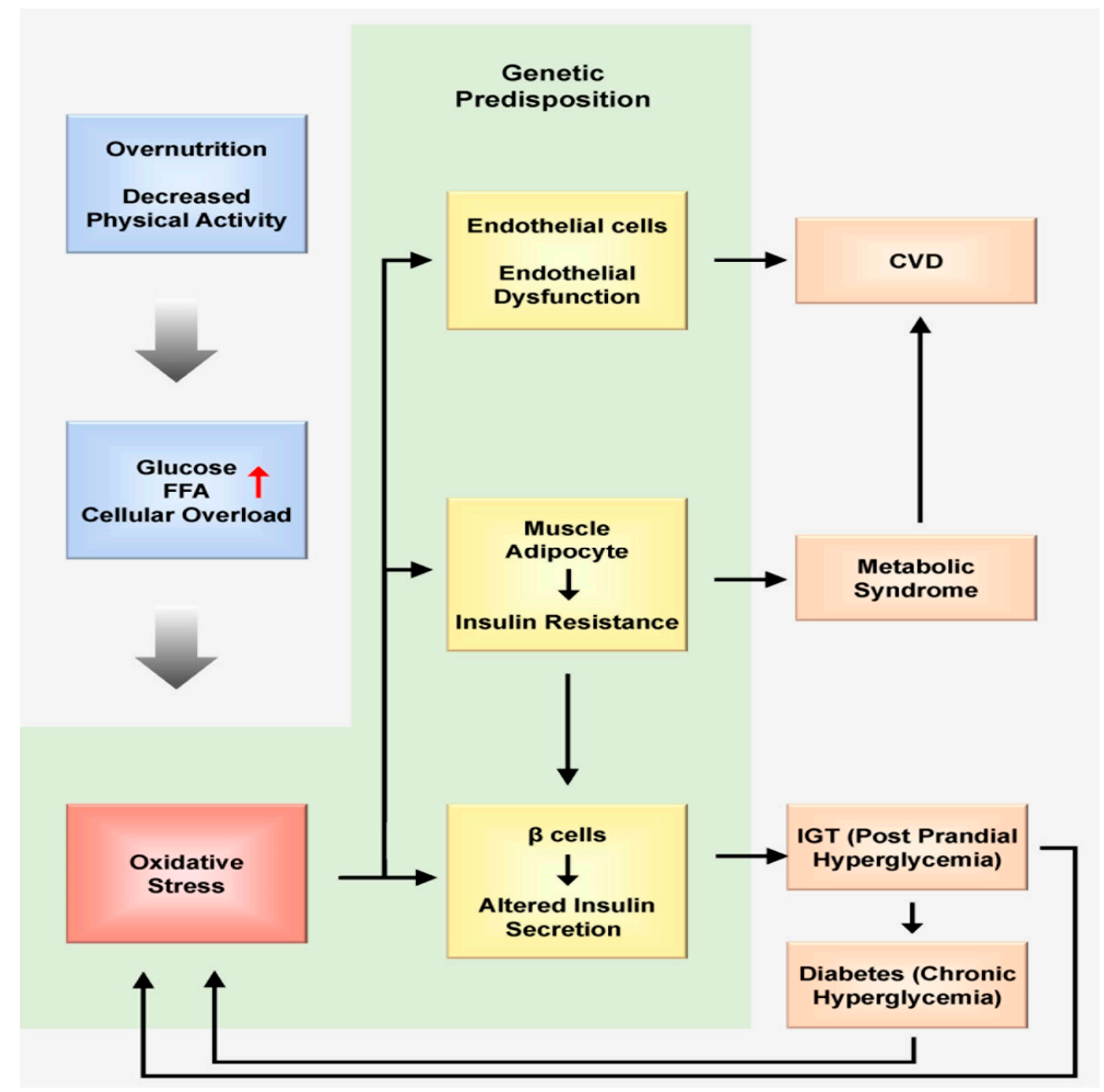

Figure 1. Overnutrition and decreased physical activity lead to overloaded glucose and free fatty acid (FFA) levels in cells. Their conversion into energy is supplemented by augmented free radical generation (oxidative stress). The muscle adipocytes can defend themselves from this situation and exhibit insulin resistance, aiming to decrease glucose and FFA permeation into the cells. The endothelial and $\beta$ cells are insulin-independent. In these cells, glucose and FFA overload may cause oxidative stress, which in turn induces dysfunction of both endothelial and $\beta$ cells. Endothelial dysfunction may induce cardiovascular disease (CVD), and $\beta$ cell dysfunction is characterized by altered insulin secretion. $\beta$ cell dysfunction is particularly characterized by a decrease in first-phase insulin secretion, which in turn produces the clinical situation of impaired glucose tolerance (IGT). This last condition is clinically characterized by increased postprandial hyperglycemia. Postprandial hyperglycemia induces oxidative stress. The persistence of this condition exhausts $\beta$ cells, leading to overt diabetes. Oxidative stress produced during both IGT and overt diabetes may contribute to the development of CVD. Moreover, the cluster of risk factors that accompany insulin resistance also contributes to CVD development. Red colored arrow represents overload (Adapted from [49]).

\subsection{Nutrition Increases Oxidative Stress during Tissue Metabolism}

Nutrient consumption elicits a major oxidative and inflammatory effect at the cellular level, which alters tissue metabolism. Nutritional oxidative stress after carbohydrate, protein, and lipid intake results in a domino of metabolic alterations in various tissues, including the liver, adipose tissue, pancreatic $\beta$-cells, and skeletal muscle. These active but metabolically distressed tissues interacting with nutrients further augment oxidative stress, eventually resulting in an infinite vicious cycle (Figure 2). 


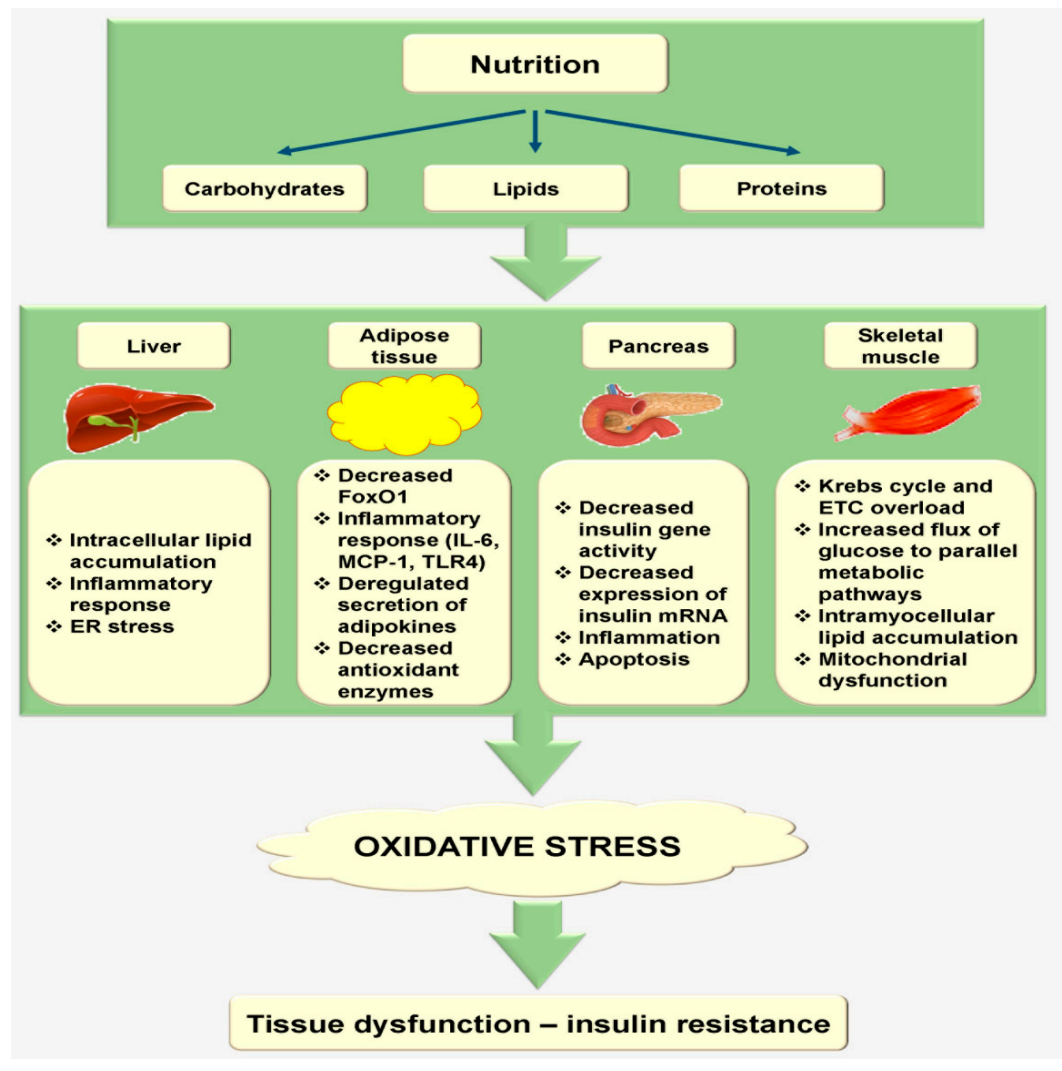

Figure 2. Nutrition mediates oxidative stress at the metabolic tissue level. Dietary fat (lipids) induces intracellular lipid accumulation in the liver and subsequently causes the inflammatory response and ER stress, which ultimately results in oxidative stress- and insulin resistance-induced liver dysfunction. A nutritious diet can induce the inflammatory response and impair FoxO1 expression, adipokine secretions, and antioxidant enzyme activity in the adipose tissue, resulting in an increased ROS generation, which ultimately causes dysfunction of the adipose tissue. In pancreatic $\beta$-cells, hyperglycemia can induce mitochondrial ROS production promoting a native oxidative microenvironment, which unfortunately changes insulin gene expression and activity that further increases oxidative stress, including inflammation generation, consequently collapsing $\beta$-cell function. Overfeeding and increased dietary fat (lipids) appeared to enhance mitochondrial dysfunction, with decreased ATP synthesis, attenuated mitochondrial gene expression, and augmented ROS generation. Consequently, a vicious cycle occurs as these mitochondrial dysfunctions further intensify the metabolic abnormalities of the skeletal muscle. ER: endoplasmic reticulum, FoxO1: Forkhead box protein O1, IL-6: Interleukin 6, MCP-1: Monocyte chemoattractant protein-1, TLR4: Toll-like receptor 4, ETC: electron transport chain. (Adapted from [60]).

\subsubsection{Liver}

Dietary fat intake or overfeeding augments free fatty acid (FFA) supply in the liver, which can affect liver metabolism by the accumulation of intracellular lipids. In the liver tissue, increased malonyl-CoA levels stimulate de novo FA production and prevent carnitine palmitoyltransferase-1 (CPT-1) function. Consequently, fatty acids (FAs) cannot be broken down in the mitochondria and are diverted to other metabolic pathways, resulting in the formation of ceramides, diacylglycerol (DAG), and triacylglycerol (TAG) [61]. In a rat model, fat-rich meal administration for only three days led to a three-fold increase in liver lipid accumulation, without any significant growth in the skeletal muscle or visceral fat content, suggesting that liver insulin resistance may precede systemic insulin resistance (Figure 2) [62]. As stated above, these lipids recruit numerous inflammatory factors that derestrict insulin signaling, including the c-Jun N-terminal kinase (JNK) and protein kinase C (PKC) pathways. 
Additionally, in an investigational model, FFA-containing cultured hepatocytes exhibited augmented levels of prothrombotic and oxidative markers, such as nitric oxide (NO), plasminogen activator inhibitor-1 (PAI-1), and malondialdehyde (MDA) [63]. Concurrently, massive substrate supply and liver overfeeding expose the ER to a substantial anabolic load that accordingly stimulates ER stress and protein misfolding, which can induce inflammatory signaling activation and ROS generation (Figure 2) [61]. Lastly, lipid accumulation in the hepatic cells affects hepatic glucose production in impaired insulin-mediated suppression and hyperlipidemia, categorized by elevated hepatic clearance of high-density lipoprotein (HDL)-cholesterol combined with elevated secretion of very low-density lipoproteins (VLDL) [64].

\subsubsection{Adipose Tissue}

In the adipose tissue, ROS production and oxidative metabolism play major roles in adipogenesis [65]. Various sources are involved in producing intracellular ROS in adipocytes. Although adipocytes are not thought to be pure energy-producing cells, ROS may be generated from electron transport chain (ETC) substrate overload as well as from mitochondria [66]. Moreover, several enzymes can induce ROS generation in adipocytes, including nicotinamide adenine dinucleotide phosphate (NADPH) oxidase. In adipocytes, NADPH oxidase 4 (NOX4) is the core isoform and its expression is augmented in the fat cells upon exposure to enriched nutrient derivatives, including glucose or palmitate [67]. Knockdown of NOX4 in adipocytes (3T3-L1 cells) prevented glucoseand palmitate-stimulated ROS production, indicating the significance of non-mitochondrial ROS in adipocytes [68].

Upon intake of a meal, an inflammatory response occurs in the adipose tissue [69]. A study conducted on rat visceral adipose tissue showed that rats fed with a fatty meal showed an acute postprandial stimulation of inflammatory signaling [70]. Similarly, in humans, $6 \mathrm{~h}$ after the feeding of a mixed meal, a similar upregulation of MCP-1 and IL- 6 was noted within the adipose tissue in normal-weight, overweight, and obese subjects, independent of the grade of adiposity (Figure 2) [71]. In addition, the change in postprandial inflammatory effects in the adipose tissue due to the specific quantity and quality of dietary fat was studied by various scientific groups, but their results are conflicting. A study involving 75 subjects with metabolic syndrome revealed that as compared to long-term ingestion of saturated fat diet, that of high-monounsaturated fat diet led to a weakened postprandial inflammatory effect in the adipose tissue [72], whereas another study indicated that individuals with metabolic syndrome displayed impaired postprandial adipose tissue inflammation, regardless of the quantity and the quality of fat ingested [73]. From the direct stimulation of inflammatory pathways by nutrient consumption, a high-fat diet may prompt native inflammation in the adipose tissue through the discharge of unnecessary FFAs. The responses of FFAs in the inflammatory pathways are facilitated through the Toll-like receptor (TLR-4), which further induces the secretion of different cytokines and macrophage aggregation in the adipose tissue (Figure 2) [74].

Overall, oxidative stress can also be identified postprandially in adipocytes. In cultured adipocytes, elevated FFA levels augmented oxidative stress via NADPH oxidase stimulation, and oxidative stress directly caused dysfunctional secretion of adipokines. Additionally, increased ROS generation caused by increased expression of NADPH oxidase and decreased expression of antioxidative enzymes was investigated in the adipose tissue of overweight mice [75]. Thus, nutrition-activated oxidative stress likely leads to a contrary native redox status that could affect the role of free radicals in the adipose tissue (Figure 2) [76].

\subsubsection{Pancreas}

Oxidative stress can also likely compromise pancreatic $\beta$-cell function, as $\beta$-cells are inherently sensitive to oxidative stress. In a previous study, $\beta$-cells exposed to $\mathrm{H}_{2} \mathrm{O}_{2}$ generated cyclin- and p21-dependent kinase inhibitors and downregulated insulin mRNA, calcium flux, and ATP reduction in the cytosol and mitochondria [77]. Moreover, $\beta$-cells express low levels of antioxidant enzymes, 
such as catalase, superoxide dismutase (SOD), and glutathione peroxidase, and are more sensitive to detrimental ROS actions [78]. Hence, oxidative stress, induced by elevated FFA and glucose levels, insulin resistance, and long-term inflammation through the above-stated mechanisms, clearly plays a role in pancreatic cells and alters insulin secretion (Figure 2) [16].

In patients with diabetes, long-term induction of plasma FFA and glucose levels has damaging effects on the pancreatic cell function [16]. An in vitro study showed that the islets or HIT-T15 cells cultured in high concentrations of FFA and glucose exhibited reduced levels of insulin mRNA and gene function and altered glucose-induced insulin secretion pathway [79]. Aberrant free radical production and oxidative stress could be one of the crucial mechanisms underlying these instabilities (Figure 2). Moreover, hyperglycemia by itself can augment intracellular mitochondrial ROS generation in pancreatic $\beta$-cells, triggering a native oxidative microenvironment, which incidentally alters several metabolic signaling pathways that further intensify oxidative stress [80], including long-term low-grade AGE and inflammation generation, consequently collapsing $\beta$-cell function (Figure 2) [81].

\subsubsection{Skeletal Muscle}

Regarding metabolic circulation, the skeletal muscle can also be characterized as a pathway controller. This tissue represents a crucial source of energy generation and accounts for approximately $80 \%$ of the postprandial insulin-induced glucose dumping [82]. As a pure energy-generating organ, skeletal muscle is packed with mitochondria that control energy homeostasis.

After nutrient feeding, insulin induces glucose entry in the skeletal muscle through glucose transporter type 4 (GLUT4) [83]. This is a cardinal phase in the body's metabolic pathways as fuel consumption should be attuned to fuel obtainability. The capability of skeletal muscle to mainly shift from lipid oxidation and high amounts of FA utilization in fasting situations to glucose ingestion, oxidation, and storage under insulin-prompted circumstances is recognized as metabolic flexibility. The inability to shift from lipid to carbohydrate use (metabolic inflexibility) was investigated in obese patients and is accompanied with intra-myocellular lipid aggregation and insulin resistance (Figure 2) [84]. Numerous factors regulate the metabolic flexibility of a subject, including nutrient presence, plasma FFA levels, the accessibility of the adipose tissue for lipid storage, and their level of physical activity [85]. Another factor that may be associated with metabolic flexibility is mitochondrial oxidative capability. Although a study showed contradictory data, it was suggested that mitochondrial aberrations in the muscle could stimulate metabolic flexibility to lipids and prompt insulin resistance (Figure 2) [85].

In the skeletal muscle, dietary habits may also disturb physiological metabolic developments and their role through direct changes in the mitochondrial biology [86]. Together, increased dietary fat and overfeeding appeared to induce mitochondrial inactivity, with declined ATP synthesis, altered mitochondrial gene expression, and augmented ROS generation. Consequently, a vicious cycle occurs as these mitochondrial dysfunctions further intensify the metabolic abnormalities of the skeletal muscle (Figure 2).

\subsection{Nutrition Induces Oxidative Homeostasis}

Nutrition-stimulated inflammatory and oxidative status in severe settings can alter extracellular and intracellular physiological activities. When these instabilities are recurrent, they execute a persistent inflammatory and oxidative response, which, in some cases, can prompt multiple diseases.

Limited-calorie dietary patterns can provoke the precise reverse effect, promoting cell longevity and securing oxidative balance. For instance, six months of caloric limitation significantly diminished oxidative stress and declined fasting insulin levels and body core temperature in healthy subjects [87]. Moreover, the study showed improved basal endothelial function and augmented plasma antioxidant capability in patients with diabetes, who followed a Mediterranean diet for three months in comparison with those patients on control diets [88]. 
Overall, evidence suggests that diet regulates oxidative stability both in an acute and in a chronic state. Nutritional variance can easily interrupt this cellular stability, initiate unfavorable pathophysiological pathways, and stimulate the incidence of numerous diseases in humans.

\section{The Relationship between Nutrition and Oxidative Stress Following Carcinogenesis}

The worldwide cancer burden is anticipated to increase by more than two-fold over the next two decades [89], therefore worsening a massive public health and medical care problem. Physical activity, nutrition, and diet rank high among the most important risk factors for human cancer, in part because of their influences on obesity, which is a recognized risk factor for various malignancies [90-95]. The role of some specific nutrients in cancer etiology has been proposed based on associations stated in epidemiological studies, further supported by biological credibility. The ultimate carcinogen is known as chemically reactive and activated form of a pro-carcinogen or carcinogen that is capable of a direct covalent binding to protein and/or nucleic acid macromolecules. The ultimate carcinogen directly binds with a cell component (probably DNA) to initiate carcinogenesis. These factors are linked to the antioxidant status of selected nutrients, impact on epigenetic functions, DNA adducts, DNA repair, regulation of gene expression, inflammation, stimulation of growth factors, or influence on circulating intensities of endogenous hormones (Figure 3) [96-98]. Incessant exposure to environmental carcinogens and inhalation chemicals is assumed to induce the amount of cytochrome P450 CYP1A1 expression in extrahepatic tissues via the aryl hydrocarbon receptor (AhR) [99-102]. Though the latter has long been identified as a ligand-activated transcription factor (TF), which is accountable for the xenobiotic inducing pathway of numerous phase I and phase II metabolizing enzymes, recent studies propose that $A h R$ is associated with several cell signaling pathways critical to cell cycle modulation and normal homeostasis [101,102]. Alteration of these pathways is associated with tumor progression. Moreover, it is increasingly evident that P450 plays a vital role in the detoxification of environmental carcinogens, following the metabolic activation of dietary compounds (nutrition) with cancer preventative activity (Figure 3) [102]. Along with other crucial factors, such as diet, energy balance, BMI, physical activity, and metabolic rate, nutrition may also influence DNA replication of cancer cells following cancer progression. Therefore, nutrition-mediated oxidative stress plays a crucial role in carcinogenesis. Some of the vital dietary components that have an association with oxidative stress following different aspects of carcinogenesis have been discussed in this section (Table 1 and Figure 4).

\subsection{Alcohol}

Alcohol is a prominent carcinogen linked with breast, oropharyngeal, colorectal, liver, and esophageal cancers [103]. Excessive consumption of alcohol also leads to fibrotic changes in the liver [104,105]. Moreover, it leads to the production of ROS following oxidative stress, which, consequently, causes severe dysfunction and damage to the biological signaling molecules [106]. Additionally, it disrupts intra- and extra-cellular network and functions, which ultimately cause chromosomal abnormalities, DNA damage, DNA methylation modification, signaling pathway alteration, tumor necrosis factor $\alpha$ (TNF- $\alpha$ ) release, and retinoid metabolism impairment, consequently, leading to cancer initiation [107-110]. Functional diversity in the genes associated with alcohol metabolism can result in varying exposure to the carcinogenic metabolites of alcohol; therefore, identifying genetic intolerance to alcohol can aid in cancer prognosis [111]. For instance, people with a common genetic mutation in the alcohol dehydrogenase gene that suppresses enzyme activity have a higher risk of esophageal cancer than those who have a fully active enzyme [103]. Alcohol facilitates its mutagenic effects by the derivation of acetaldehyde adducts, induction of the activity of Kupffer cells, and enhancing oxidative stress by augmenting formation of gut-derived endotoxins [110]. Alcoholism results in accumulation of acetaldehyde, which, consequently, causes genotoxicity. A similar change occurs due to accumulated acetaldehyde in hepatocellular carcinoma [112,113]. Moreover, according to World Cancer Research Fund (WCRF) analysis, alcohol intake is significantly correlated with increased breast 
cancer risk [90]. Numerous epidemiological studies supported a positive interaction between breast cancer risk and alcohol [114]. A meta-analysis revealed that high alcohol consumption (10 $\mathrm{g}$ of ethanol consumption per day) was highly associated with risks for $\mathrm{ER}^{+} \mathrm{PR}^{+}, \mathrm{ER}^{+} \mathrm{PR}^{-}, \mathrm{ER}^{+}$, and $\mathrm{ER}^{-}$breast tumors, but not $\mathrm{ER}^{-} \mathrm{PR}^{-}$tumors [115]. Additionally, there are several contradictory studies on the probable relationship of alcohol consumption with numerous histological grades or stages of prostate cancer [116-120]. Previous meta-analyses have also emphasized these irregularities, highlighting the necessity for further studies in this area [121,122].

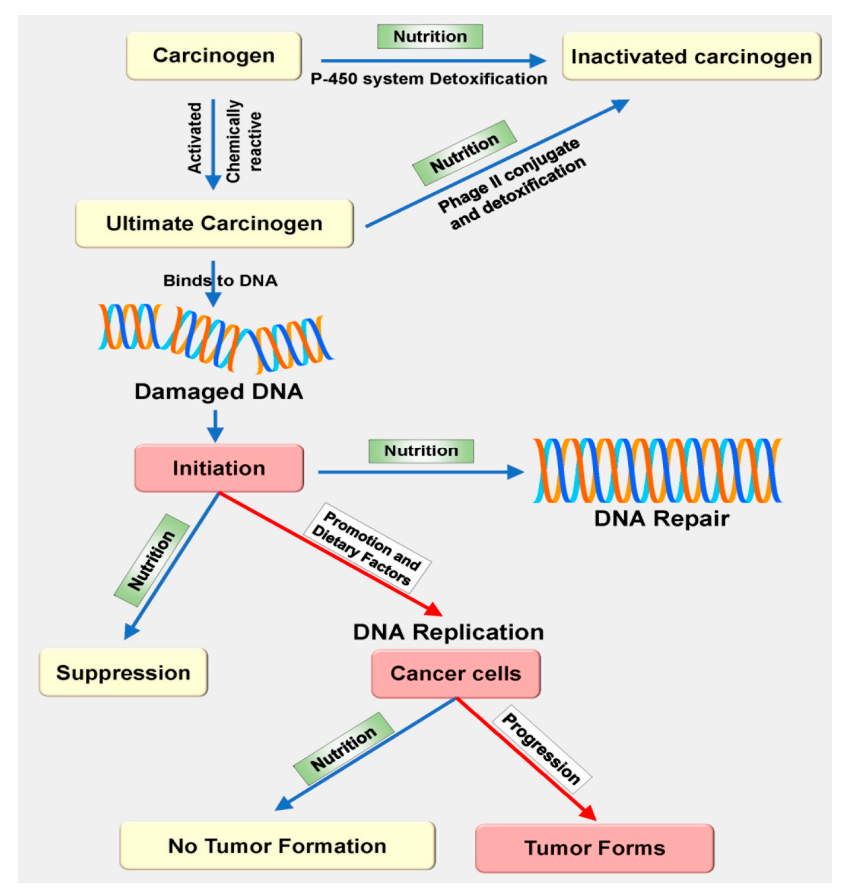

Figure 3. Nutrition as a mediator of cancer suppression at the molecular level. A chemically reactive and activated form of pro-carcinogen or carcinogen (ultimate carcinogen) is capable of direct covalent binding to protein and/or nucleic acid macromolecules. It directly binds to a cell component (probably DNA) to initiate carcinogenesis. The preventive function of nutrition can be activated by the enzymes (cytochrome P450) in carcinogenesis. Cancer cells can form a tumor by the action of various dietary factors. Metabolically active nutritional compounds can defend carcinogenesis by suppressing the activity of carcinogen or by inducing DNA repair mechanism. Blue colored arrows represent beneficial effect and red colored arrows represent harmful effect of nutrition [99-102].

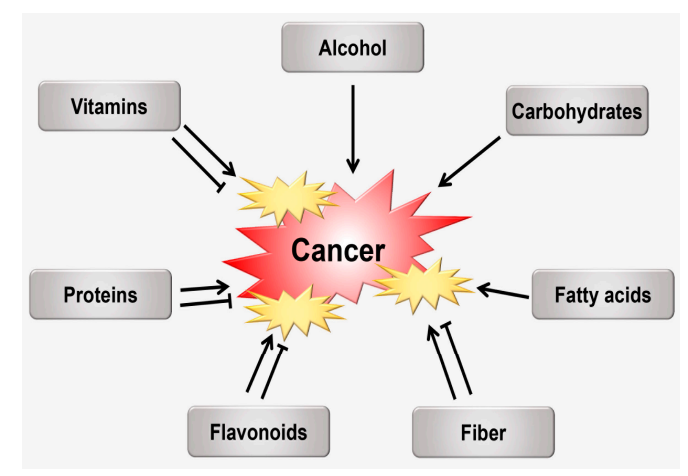

Figure 4. Some vital dietary factors have been associated with various aspects of cancer progression. Arrows represent activation of cancer and $\mathrm{T}$ bar represent inhibition. 
Table 1. The role of various dietary components in oxidative stress and carcinogenesis.

\begin{tabular}{|c|c|c|c|}
\hline No. & Dietary Components & Role in Oxidative Stress & Role in Carcinogenesis \\
\hline 1 & Alcohol & $\begin{array}{l}\text { - Promotes ROS production while lowering cellular antioxidant levels, thereby } \\
\text { altering homeostasis between pro- and anti-oxidants leading to oxidative } \\
\text { stress in multiple tissues [123]. } \\
\text { - Increases ROS production and oxidative stress, and results in the } \\
\text { accumulation of acetaldehyde [124]. } \\
\text { - alters mitochondrial function resulting in cellular death [125]. }\end{array}$ & $\begin{array}{l}\text { - Prominent carcinogen linked with several cancers [95]. } \\
\text { - Higher risk for esophageal cancer [95]. } \\
\text { - Highly associated with risks for breast tumors [115]. } \\
\text { - Alcohol intake and the genes involved in alcohol metabolism and their interaction increase the } \\
\text { risk of breast cancer in post-menopausal women [126]. } \\
\text { - Chronic alcohol abuse can cause folate deficiency, which is a well-documented risk factor for } \\
\text { breast cancer [127]. }\end{array}$ \\
\hline 2 & Carbohydrates & $\begin{array}{l}\text { - Lead to increased oxidative stress, which has been associated with increased } \\
\text { risk for atherosclerosis and related disorders [128]. } \\
\text { - High-carbohydrate meal may evoke a greater postprandial oxidative stress } \\
\text { response [129]. }\end{array}$ & $\begin{array}{l}\text { - Could affect breast cancer influencing plasma levels of glucose and insulin, and insulin } \\
\text { resistance [130]. } \\
\text {. Consuming foods with high insulinogenic content may increase the risk of breast cancer [131]. }\end{array}$ \\
\hline 3 & Fatty acids (FAs) & $\begin{array}{l}\text { - Omega-3 FAs reduce oxidative stress [132]. } \\
\text {. FAs shorten in chain length and decrease unsaturation and peroxidation, } \\
\text { while the 1-carbon cycle shifts from the methylation to the transsulfuration } \\
\text { pathway [133]. }\end{array}$ & $\begin{array}{l}\text { - Established mechanism is an association between inflammatory pathways and the function of } \\
\text { omega-3 and omega-6 FAs on the action of cyclooxygenase-2 (COX-2) in prostate cancer [134-136]. } \\
\text { - n-3 FAs, especially the long-chain polyunsaturated FAs, eicosapentaenoic acid and } \\
\text { docosahexaenoic acid, present in fatty fish and fish oils inhibit carcinogenesis [137]. }\end{array}$ \\
\hline 4 & Fiber & $\begin{array}{l}\text { - Could protect from oxidative stress [138]. } \\
\text { - Reduced levels of oxidative stress [139]. } \\
\text { - Elicited modest improvements in indices of oxidative stress and } \\
\text { inflammation [140]. } \\
\text { - Dietary fiber supplementation, rather than energy intake and dietary } \\
\text { restriction, appears to be the main process regarding oxidative stress in the } \\
\text { cardiac tissue [141]. }\end{array}$ & $\begin{array}{l}\text { - An } 11 \% \text { decrease in breast cancer risk in individuals consuming a fiber-rich diet versus that in } \\
\text { individuals consuming the lowest amount of fiber [142]. } \\
\text { - With up to a } 25 \% \text { reduction in cancer risk when ingesting around } 12.6-33.1 \mathrm{~g} / \text { day of fiber, or } 17 \% \\
\text { reduction for consuming fiber } 3 \text { times a day }[143,144] \text {. } \\
\text { - It reduces the risk of developing some types of cancer [145]. }\end{array}$ \\
\hline 5 & Flavonoids & $\begin{array}{l}\text { - Prevent disuse muscle atrophy by attenuating oxidative stress derived from } \\
\text { mitochondrial dysfunction [146]. } \\
\text { - Have potential antioxidant actions by reacting with and inactivating } \mathrm{O}_{2}{ }^{-} \text {, } \\
\text { oxygen lipid peroxide radicals, and/or stabilizing free radicals involved in the } \\
\text { oxidative process by hydrogenation or complexing with oxidant species [147]. } \\
\text { - Have both a cytoprotective effect owing to ROS scavenging and cytotoxic } \\
\text { effect caused by } \mathrm{H}_{2} \mathrm{O}_{2} \text { generation [148]. }\end{array}$ & $\begin{array}{l}\text { - Isoflavones are the most well-known compounds that possess well-characterized anti-estrogenic } \\
\text { activity; functions in intracellular steroid metabolism; and anti-angiogenic, anti-proliferative, } \\
\text { and pro-apoptotic activities in various tumor cells [149-151]. } \\
\text {. Isoflavones consumption of } 20 \mathrm{mg} / \text { day can decrease breast cancer risk by } 29 \% \text { compared to that } \\
\text { by consumption of } 5 \mathrm{mg} / \text { day [152]. } \\
\text { - Flavonoids are potent regulators of cyclin B and p21 required for cell cycle progression, which } \\
\text { may play some roles in the prevention of carcinogenesis [153]. } \\
\text { - Flavonoids have emerged as potential chemopreventive candidates for cancer treatment, } \\
\text { especially, by their ability to induce apoptosis [154]. }\end{array}$ \\
\hline 6 & Proteins & $\begin{array}{l}\text { - Long-term intake of high protein diets did not increase variables of oxidative } \\
\text { stress [155]. } \\
\text { - Become activated by oxidation and help bacteria to respond to oxidative } \\
\text { stress [156]. }\end{array}$ & $\begin{array}{l}\text { - Protein-rich food (especially animal protein) could be associated with a higher risk of cancer [157]. } \\
\text { - Colorectal cancer progression occurs upon satisfactory consumption of animal protein [158]. }\end{array}$ \\
\hline 7 & Vitamins & $\begin{array}{l}\text {. Vitamin A is rapidly oxidized in the presence of oxygen, transient metals, } \\
\text { and light [159]. } \\
\text {. Vitamin E plays an important protective antioxidant role in elderly, } \\
\text { particularly in conditions where oxidative stress and free radicals are } \\
\text { potentiated [160]. }\end{array}$ & $\begin{array}{l}\text { - Numerous vitamins, including vitamin A, B, C, D, and E, have been implicated in the risk of } \\
\text { cancer occurrence [161-165]. } \\
\text { - Intake or synthesis of vitamin D is associated with reduced incidence and death rates of colon, } \\
\text { breast, prostate, and ovarian cancers [166]. }\end{array}$ \\
\hline
\end{tabular}




\subsection{Carbohydrates}

Ingestion of nutritional carbohydrate, a key dietary factor, disturbs an individual's glycemic response and insulin secretion, while consequences differ depending on the amount of carbohydrates consumed [167]. Carbohydrate quality could affect cancer risk, especially, that of breast cancer, significantly by influencing plasma levels of glucose and insulin, and insulin resistance [130]. Recent meta-analysis studies described a potential relationship between glycemic index (GI), degree of cancer risk, and intake of carbohydrate quality [168-171]. Previous studies suggest that oxidative stress may have an important role connecting acute hyperglycemia to augmented cardiovascular risk [172-174]. Acute enhancement in blood glucose concentrations may increase the formation of free radicals by an imbalance in the ratio of NADH to NAD and by non-enzymatic glycation increased by glucose in cells $[175,176]$. The direct indication from studies presented that enhanced hyperglycemia or meal consumption and its derived glucose can promote oxidative stress and impair antioxidant defenses $[177,178]$. Consequently, oxidative stress was significantly augmented after food intake that produced a superior degree of hyperglycemia in both normal subjects and those with diabetes [179]. According to the European Prospective Investigation into Cancer and Nutrition (EPIC), increased carbohydrate and glycemic burden in the food were associated with an increase in $\mathrm{ER}^{-} / \mathrm{PR}^{-}$and $\mathrm{ER}^{-}$ breast cancer among older women [180]. Similarly, the Women's Health Initiative (WHI) suggested that consuming foods with high insulinogenic content may increase the risk of breast cancer [131]. Together, the potential relationship between cancer risk and dietary GI was more commonly stated by case-controls than by the cohort studies. A probable purpose for this is that case-control reports are more liable to problems of remembering and selection difficulty than cohort studies are. In addition, most case-control studies were conducted in Europe and most cohort studies were conducted in North America. The diverse results between studies performed in North Americans and Europeans may also reveal variances in nutritional lifestyles between the two regions. Individuals from Europe ingest carbohydrate-enriched food and different kinds of carbohydrates [181] compared to individuals in North America [182], who consistently consume more fats. Studies are often unable to demonstrate a relationship between oxidative stress-induced cancer risk and carbohydrate intake.

\subsection{Fatty acids (FAs)}

Dietary lipids or fats are frequently blamed as the key source of superfluous energy. When caloric consumption surpasses energy expenses, the resultant substrate-induced enhancement in citric acid cycle activity produces an excess of ROS. Moreover, dietary FA ingestion influences the relative FA configuration of biological membranes defining its sensibility to oxidative changes [183]. There are huge controversies around finding a relationship between FA-rich meals and cancer risk in population-based reports, despite a solid biological credibility underlying these relationships. The role of inflammation in membrane fluidity and functions, stimulation of growth factors, and regulation of gene expression, or its effect on circulating levels of endogenous hormones has been cited. Recent data demonstrate a link between dietary FA with induced oxidative stress and carcinogenesis in the rat model [184]. Several epidemiological studies mention that, rather than total dietary fat ingestion, subgroups of FAs could differentially affect cancer risk [185-188]. Essential FAs (EFAs) of the omega-3 family ( $\alpha$-linolenic acid, docosahexaenoic acid (DHA), and eicosapentaenoic acid (EPA)) and omega- 6 family (arachidonic acid and linoleic acid) have been a vast subject of study, because of their dietary significance and their association with the prognosis of various types of cancers. In spite of numerous studies conducted over the last decades, recent scientific data are debatable and there is a lack of reliable conclusions about the effect of EFAs and the risk of breast, bladder, colorectal, lung, or prostate cancers [189-192]. In the broad literature regarding this type of EFA (omega-3, omega-6, and omega-3/omega-6 ratio) and its relationship to cancer progression, several underlying mechanisms have been hypothesized. One of the most established mechanisms is an association between inflammatory pathways and the function of omega- 3 and omega-6 FAs on the action of cyclooxygenase-2 (COX-2) in prostate cancer [134-136]. On the contrary, Gao et al. [193] demonstrated 
that palmitate, a saturated FA, up-regulated COX-2 via NF- $\mathrm{kB}$-dependent mechanism; consequently, COX-2-associated oxidative stress weakened endothelium-dependent relaxations in the mouse aortas. However, metabolic characteristics of these EFAs are completely conflicting. The COX-2 enzyme can convert omega-6 FAs into prostaglandin E2, a pro-inflammatory cytokine, which enables angiogenesis and cell proliferation, whereas prostaglandin E3 is produced from omega-3 FAs with the help of COX-2, which does not facilitate mitogenic characteristics [194].

This proposal could elucidate the results achieved by assessing the impact of the omega-3/omega- 6 ratio on melanoma [195], and the effects of DHA- and EPA-rich fish oil on colorectal [196] or prostate cancer, where the diversity of results leads to contradictory conclusions $[197,198]$.

\subsection{Fiber}

Consumption of whole grain cereals, vegetables, and fruits provides the fibers necessary for our health, with the recommended intake being approximately $21-38 \mathrm{~g} /$ day. The protective action of fibers is not only associated with colorectal cancer, but also with other cancer types. A study showed an $11 \%$ decrease in breast cancer risk in individuals consuming a fiber-rich diet versus that in individuals consuming the lowest amount of fiber [142]. This association is dose-dependent; cancer risk decreased $7 \%$ with each $10 \mathrm{~g} /$ day of fiber intake, which is not dependent on the ethnic group, region, or menopausal status [142]. Moreover, the WCRF assessment board concluded an inadequate level of data regarding the relationship between dietary fiber and breast cancer risk [90]. Similarly, an organized review and meta-analysis of potential studies presented a significant inverse relationship between nutritional fiber intake and breast cancer risk [143]. In addition, the recent epidemiological proof is not convincing regarding the ability of fiber intake to decrease colorectal cancer risk. Some studies have shown significant results, with up to a $25 \%$ reduction in cancer risk by ingesting around $12.6-33.1 \mathrm{~g} /$ day of fiber, or $17 \%$ reduction by consuming fiber three times a day, though some studies have not found any beneficial effects [144,199].

\subsection{Flavonoids}

Cancer initiation and progression have been associated with oxidative stress by enhancing DNA mutations or increasing DNA damage, genome variability, and cell proliferation, and hence antioxidant agents could intervene with carcinogenesis [200]. Among the antioxidant compounds, isoflavones are the most well-known compounds that possess well-characterized anti-estrogenic activity (antagonistic for the $\beta$-estrogen receptor); functions in intracellular steroid metabolism (inhibiting the enzyme that transforms androgen to estrogen); and anti-angiogenic, anti-proliferative, and pro-apoptotic activities in various tumor cells [149-151]. Other flavonoid compounds, polyphenols, have anticancer activity both in humans and animal models [201,202]. Currently, increasing attention is directed towards the role of natural antioxidant agents on modulating intracellular ROS levels resulting into epigenetic alterations of essential genes in tumorigenesis [202]. Several flavonoids were confirmed to disrupt the enzymes leading to epigenetic modifications, which regulate the inflammation process that might oscillate in cancer [202]. Excessive ROS generation may lead to tissue injury that may induce inflammatory process [203], the inflammatory mediators may be involved in various chronic diseases, including CVD, neurological disease, and carcinogenesis [204]. Although in vitro studies depict a positive outcome, case-control results and phase III clinical trials afford unconvincing data for certain kinds of tumors, such as breast or prostate neoplasms [151,205]. A study on Asian women revealed that isoflavone consumption of $20 \mathrm{mg} /$ day can decrease breast cancer risk by $29 \%$ as compared to that after consumption of $5 \mathrm{mg} /$ day [152]. On the contrary, according to a meta-analysis, no association was found in western women, even though these women ingested $0.8 \mathrm{mg}$ of isoflavones per day [151]. Previously, studies have stated that Asian men consume high amounts of isoflavone-containing foods, while western counterparts consume mostly red meat-containing foods with minimal isoflavones [206-208]. This variation in results can be caused by numerous factors, 
including dose and type of isoflavones, type of cancer, or even diverse enzymatic polymorphisms between subjects [209].

\subsection{Proteins}

In a nutritional diet, protein is the most important element for human health. Proteins contain no nutritional value until they are digested by protease and peptidase enzymes. Excessive protein consumption can induce amino acid oxidation and urea synthesis [210], and impair the nutritional efficacy of energy utilization [211]. An interesting study stated that high protein intake could obliterate the stability of antioxidants and oxidation of amino acids in the digestive system of mice and promote generation of ROS in the digestive gland [212]. A conceivable explanation is that ROS might be generated after meat consumption during its metabolism [213]. Moreover, high-protein ingestion can result in oxidative stress, inducing risk for long-term diseases, including carcinogenesis [214-216]. In patients with cancer, protein consumption is decreased tremendously due to reduced digestion, low food intake, and augmented catabolism [217]. Recently, an epidemiological study showed that intake of protein-rich food (especially animal protein) could be associated with a higher risk of cancer [157]. Moreover, a few epidemiological studies have discovered an association between intake of animal protein (e.g., red meats) and several diseases (e.g., hypertension and colon cancer) [218,219]. There are no particular enduring clinical trials analyzing meatless diets for children or adults. Similarly, there is little evidence indicating that colorectal cancer progression occurs upon satisfactory consumption of animal protein [158]. Recent studies from large cohorts, such as the Health Professional Follow-up Study, the Nurse's Health Study, and the Multiethnic Cohort, depicted insignificant or inverse correlations between ingestion of unrefined red meat and colon cancer $[218,220]$. Together, research from the interference studies on cancer and diet, including the Polyp Prevention Trial and the Women's Health Initiative, found that a reduction in dietary consumption of animal protein (e.g., processed meat and red meat) did not decrease the risk of colon cancer and/or had no outcome on adenoma relapse in the large bowel [221-223].

\subsection{Vitamins}

Recent epidemiological studies have been conducted to discover the association between vitamin consumption and the risk of cancer diagnosis. According to previous studies, numerous vitamins, including vitamin A, B, C, D, and E, have been implicated in the risk of cancer occurrence [161-165]. Vitamins C, D, and E and selenium share fundamental antioxidant properties and all protect against oxidative stress and its harmful effects in our body that lead to carcinogenesis. However, oxidative stress is a natural process with positive outcomes, such as improved immune response [224]. Previous studies stated that high-dose vitamin $\mathrm{C}$ killed cancer cells by playing a role as a pro-drug, which provides hydrogen peroxide $\left(\mathrm{H}_{2} \mathrm{O}_{2}\right)$ [225-227]. Vitamin C-induced elevated levels of ROS, including $\mathrm{H}_{2} \mathrm{O}_{2}$, are considered to play a vital role in carcinogenesis [226]. Previous studies also reported that vitamin C administration promoted cytotoxicity by ATP reduction in some cancer cells [227-229]. A case-control study involving women from Klang Valley and Selangor, Malaysia, demonstrated that a good antioxidant consumption, including vitamins $\mathrm{A}$ and $\mathrm{E}$, can reduce oxidative stress and subsequently prevent breast cancer risk [230]. The relationships between breast cancer and B vitamins have been broadly studied and these relationships are complex. From questionnaires, epidemiological studies have estimated an association between folate consumption and the risk of breast cancer with conflicting results [231]. On the contrary, preventive effects have been witnessed in individuals with low folate consumption and occasional vitamin intake [232]. Moreover, there are questionable findings for vitamin B in prostate cancer [233], for vitamins C and E in liver [234] and prostate cancers [235], and for folic acid and vitamin D in pancreatic cancer $[236,237]$. 


\section{The Association between Oxidative Stress and Cancer Progression}

An association between oxidative stress and cellular alteration was first recognized in 1981 when it was identified that insulin raised intracellular $\mathrm{H}_{2} \mathrm{O}_{2}$ levels and augmented tumor cell proliferation [238]. After more than three decades, the function of ROS in cancer progression remains conflicting. Oxidative stress is involved in various diseases, including neurodegenerative diseases [239,240], chronic inflammation [241,242], metabolic disorders [243,244], and extensively in various cancers [245-249]. The rise in ROS levels from oxidative stress, as a consequence of oncogene signaling pathways, may exploit underlying mutagenesis and genomic variability in cancer cells to stimulate cancer progression. Cancer cells require high levels of ATP because it acts as "fuel" for aberrant cell proliferation. However, the effect of this excess energy generation is the accumulation of ROS, which needs to be prevented by scavenging actions to ensure cell survival [250]. To prevent these possibly toxic effects of ROS, numerous oncogenes also augment the expression of nuclear factor erythroid 2-related factor 2 (NRF2), which diminishes ROS levels and stimulates tumorigenesis [251]. Similarly, NRF2 not only offers protection against chemical carcinogens, but also augments cancer progression by defending cancer cells from ROS and DNA damage [252-258]. In contrast, NRF2 deletion in pancreatic cancer cells augmented DNA damage and inhibited carcinogenesis [251].

Several studies have assessed ROS levels and generation under numerous conditions with the aim of determining when ROS are carcinogenic and when they are cancer suppressive [259]. At low or endurable levels, ROS may aid cancer progression either by playing as signaling elements or by stimulating alterations in genomic DNA or DNA damage. For example, ROS can promote expression of cyclin D1, phosphorylation of extracellular signal-regulated kinase (ERK) and JUN N-terminal kinase (JNK), and activation of mitogen-activated protein kinase (MAPK), all of which are connected to cancer progression and survival [260-265]. Moreover, ROS have been found to inversely incapacitate tumor suppressors, including protein tyrosine phosphatases (PTPs) and phosphatase and tensin homolog (PTEN), due to the existence of the redox-sensitive cysteine residues that exist in their catalytic sites [266-268]. Remarkably, PTPs can also control signaling pathways to induce the expression of antioxidant enzymes and diminish ROS levels [269]. Additionally, normal stem cell renewal and differentiation are controlled by ROS levels [270]; while cancer stem cells (CSCs) share similar properties with normal stem cells, comparatively little is known regarding their association with redox status. Recently, studies have shown that the liver and breast cancer stem cells tend to have low ROS levels, leading to the augmented expression of ROS-scavenging signaling proteins [270]. If CSC growth is vital for tumor initiation, then retaining low ROS levels in CSCs may be essential for the endurance of pre-neoplastic foci. Hence, although chemotherapy and radiotherapy prompt ROS generation, they are beneficial for abolishing most cancer cells, yet may be unable to cure the patient, leading to the greater capability of CSCs to endure in circumstances of high ROS by increasing antioxidants levels [250]. As ROS are debatable mediators of the adverse effects of some anticancer drugs and ionizing radiation, CSCs may be favorably released and aggressively selected by actions that depend on increased ROS levels. Furthermore, the supplementary oxidative stress prompted by these actions may cause further mutations and DNA damage, resulting in the expansion of drug-resistant cancer cells (Figure 5).

At elevated levels, ROS stimulate cell death and harmful cellular damage. In this case, cancer cells must overcome increased levels of ROS, particularly at initial stages of cancer progression. A recent study found that circumstances that enhance oxidative stress also raise the specific pressure on pre-neoplastic cells to induce influential antioxidant mechanisms [271]. Increased levels of ROS are also prompted by dissipation from the cell matrix [272]. This feature is relevant during metastasis of cancer cells that need to survive upon migration to distant organs. Thus, cancer cells typically have a high antioxidant capability that controls ROS levels and are attuned with biological functions of the cell, but are quite higher than the antioxidant capacity of normal cells. Moreover, increased ROS levels by endogenous antioxidants are unfavorable to cancer cells as well as cancer progression. We consider 
that targeting these enriched antioxidant protective mechanisms may represent an approach that can precisely destroy cancer cells, including CSCs, while sparing normal cells.

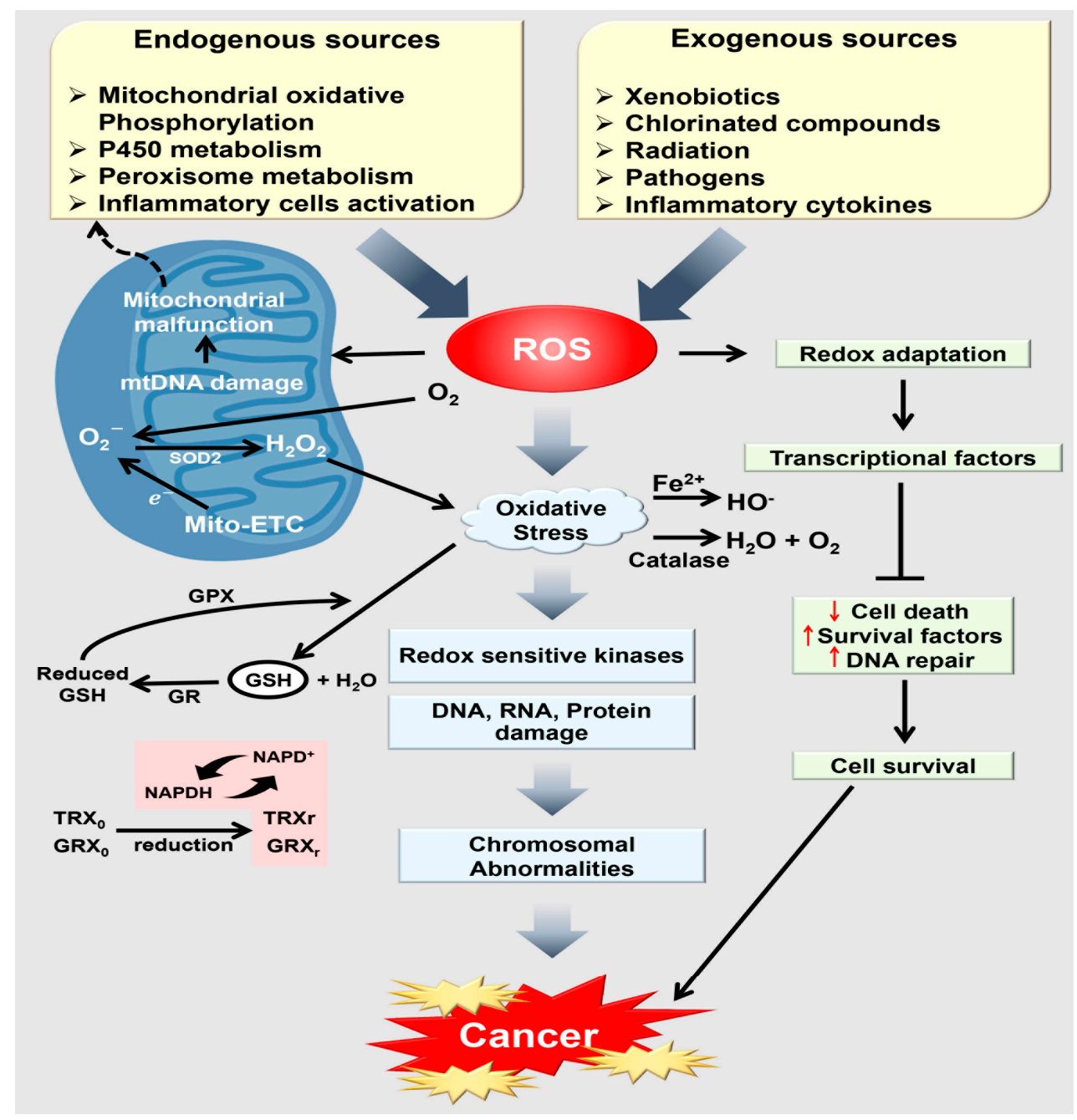

Figure 5. A schematic diagram of overall signaling pathways of cancer progression induced by oxidative stress. SOD: superoxide dismutases; Mito-ETC: mitochondrial electron transport chain, GSH: glutathione; GR: glutathione reductase; GPX: glutathione peroxidase; GRXo, glutaredoxin (oxidized); GRXr: glutaredoxin (reduced); GSHr: glutathione (reduced); TRXo, thioredoxin (oxidized); TRXr: thioredoxin (reduced). Black arrows represent activation and $\mathrm{T}$ bar represent inhibition, red colored arrows represent upregulation/downregulation. (Adapted from [273]).

\section{Conclusions}

In the human body, nutrition is one of the vital regulators of oxidative stress. Nutrient consumption and the associated postprandial oxidative stress result in the accumulation of molecular alterations in the crucial signaling pathways of several organs, critically changing the cellular milieu. However, the particular pathophysiological roles of oxidative stress and nutrition are still elusive, with targeted therapeutic modalities representing a puzzling field. Specifically, when the organs of the gastrointestinal (GI) tract are exposed to the highest amount of dietary associated carcinogens, the injurious effects of these components affect the whole body system. Over the past decades, extensive studies have revealed that alterations in the cell metabolism play a vital role in the progression of various types of cancer. In general, carcinogenesis as well as dietary carcinogen-associated carcinogenesis, is significantly correlated with chronic and/or acute oxidative stress. The precise 
nature of the effect of oxidative stress on cancer development and/or response to treatment requires further exploration. The association between nutrition and oxidative stress may have an important role in cancer and CSC progression as well as therapy. To validate and confirm all of these above-mentioned hypotheses, more detailed further investigations and research are required. Recently developed technologies, including metabolomics and deep DNA sequencing, are imperative tools that would support to define how the metabolism of cancer cells become accustomed and offers a buffer against augmented oxidative stress. However, the pathophysiological relationship between carcinogenesis and oxidative stress opens prospects for protective and even therapeutic use of beneficial, healthy dietary compounds indicated as nutraceuticals. Therefore, this review details our understanding of the correlation between nutrition, oxidative stress, and cancer development, and uncovers related crucial therapeutic strategies.

Acknowledgments: This paper was supported by Konkuk University in 2016.

Author Contributions: Subbroto Kumar Saha designed this work, collected the data, and co-wrote the manuscript. Soo Bin Lee, Jihye Won, Hye Yeon Choi, Kyeongseok Kim, Gwang-Mo Yang, and Ahmed Abdal Dayem collected the data and helped edit the manuscript. Ssang-goo Cho designed the work, collected and reorganized the data, and wrote and edited the manuscript.

Conflicts of Interest: The authors declare no conflict of interest.

\section{Abbreviations}

$\begin{array}{ll}\text { 8-OHdG } & \text { 8-OH deoxyguanosine } \\ \text { AGE } & \text { advanced glycation end product } \\ \text { ATP } & \text { adenosine triphosphate } \\ \text { BMI } & \text { body mass index } \\ \text { COX-2 } & \text { cyclooxygenase } 2 \\ \text { CPT-1 } & \text { carnitine palmitoyltransferase-1 } \\ \text { CRP } & \text { C-reactive protein } \\ \text { CSC } & \text { cancer stem cells } \\ \text { CVD } & \text { cardiovascular disease } \\ \text { DAG } & \text { diacylglycerols } \\ \text { DHA } & \text { docosahexaenoic acid } \\ \text { EFA } & \text { Essential fatty acids } \\ \text { EPA } & \text { eicosapentaenoic acid } \\ \text { EPIC } & \text { European Prospective Investigation into Cancer and Nutrition } \\ \text { ER: } & \text { endoplasmic reticulum } \\ \text { ERK } & \text { extracellular signal-regulated kinase } \\ \text { ETC: } & \text { electron transport chain } \\ \text { FFA } & \text { free fatty acids } \\ \text { FoxO1 } & \text { Forkhead box protein O1 } \\ \text { GI } & \text { glycemic indexes } \\ \text { GLUT4 } & \text { glucose transporter type 4 } \\ \text { GPX } & \text { glutathione peroxidase } \\ \text { GR } & \text { glutathione reductase } \\ \text { GRXo } & \text { glutaredoxin (oxidized) } \\ \text { GRXr } & \text { glutaredoxin (reduced) } \\ \text { GSHr } & \text { glutathione (reduced) } \\ \text { HDL } & \text { high-density lipoproteins } \\ \text { IARC } & \text { International Agency for Research on Cancer } \\ \text { IGT } & \text { impaired glucose tolerance } \\ \text { IKK } \alpha & \text { IkB kinase } \alpha \\ \text { IKK } \beta & \text { IkB kinase } \beta \\ \text { IL- } 6 & \text { Interleukin } 6 \\ \text { IKB } \alpha & \text { inhibitor } \text { kB } \alpha \\ \end{array}$




$\begin{array}{ll}\text { JNK } & \text { c-Jun N-terminal kinase } \\ \text { MAPK } & \text { mitogen-activated protein kinase } \\ \text { MCP-1 } & \text { Monocyte chemoattractant protein-1 } \\ \text { MDA } & \text { malondialdehyde } \\ \text { Mito-ETC } & \text { mitochondrial electron transport chain } \\ \text { MNC } & \text { mononuclear cells } \\ \text { NADPH } & \text { nicotinamide adenine dinucleotide phosphate } \\ \text { NF-KB } & \text { nuclear factor kB } \\ \text { NO } & \text { nitric oxide } \\ \text { NOX4 } & \text { NADPH oxidase 4 } \\ \text { NRF2 } & \text { nuclear factor erythroid 2-related factor 2 } \\ \text { PAI-1 } & \text { plasminogen activator inhibitor-1 } \\ \text { PCOS } & \text { polycystic ovarian syndrome } \\ \text { PKC } & \text { protein kinase C } \\ \text { PMNL } & \text { polymorphonuclear leukocytes } \\ \text { PTEN } & \text { phosphatase and tensin homolog } \\ \text { PTP } & \text { protein tyrosine phosphatase } \\ \text { ROS } & \text { reactive oxygen species } \\ \text { SOD } & \text { superoxide dismutase } \\ \text { TAG } & \text { triacylglycerol } \\ \text { TLR4: } & \text { Toll-like receptor 4 } \\ \text { TRXo } & \text { thioredoxin (oxidized) } \\ \text { TRXr } & \text { thioredoxin (reduced) } \\ \text { VLDL } & \text { very low-density lipoproteins } \\ \text { WCRF } & \text { World Cancer Research Fund } \\ \text { WHI } & \text { Women's Health Initiative } \\ \text { WHO } & \text { World Health Organization } \\ & \end{array}$

\section{References}

1. Ferlay, J.; Soerjomataram, I.; Dikshit, R.; Eser, S.; Mathers, C.; Rebelo, M.; Parkin, D.M.; Forman, D.; Bray, F. Cancer incidence and mortality worldwide: Sources, methods and major patterns in GLOBOCAN 2012. Int. J. Cancer 2015, 136, E359-E386. [CrossRef] [PubMed]

2. Mosby, T.T.; Cosgrove, M.; Sarkardei, S.; Platt, K.L.; Kaina, B. Nutrition in Adult and Childhood Cancer: Role of Carcinogens and Anti-carcinogens. Anticancer Res. 2012, 32, 4171-4192. [PubMed]

3. Torre, L.A.; Bray, F.; Siegel, R.L.; Ferlay, J.; Lortet-Tieulent, J.; Jemal, A. Global Cancer Statistics, 2012. CA Cancer J. Clin. 2015, 65, 87-108. [CrossRef] [PubMed]

4. Troselj, K.G.; Gueraud, F.; Glavan, T.M.; Pierre, F.; Zarkovic, N. A Review on Food-Associated Carcinogenesis. In Food Toxicology; CRC Press: Boca Raton, FL, USA, 2016; pp. 35-56.

5. Diamanti-Kandarakis, E.; Papalou, O.; Kandaraki, E.A.; Kassi, G. MECHANISMS IN ENDOCRINOLOGY Nutrition as a mediator of oxidative stress in metabolic and reproductive disorders in women. Eur. J. Endocrinol. 2017, 176, R79-R99. [CrossRef] [PubMed]

6. Commoner, B.; Townsend, J.; Pake, G.E. Free radicals in biological materials. Nature 1954, 174, 689-691. [CrossRef] [PubMed]

7. Halliwell, B. Reactive oxygen species in living systems: Source, biochemistry, and role in human disease. Am. J. Med. 1991, 91, S14-S22. [CrossRef]

8. Turrens, J.F. Mitochondrial formation of reactive oxygen species. J. Physiol. 2003, 552, 335-344. [CrossRef] [PubMed]

9. Halliwell, B. Oxidative stress, nutrition and health. Experimental strategies for optimization of nutritional antioxidant intake in humans. Free Radic. Res. 1996, 25, 57-74. [CrossRef] [PubMed]

10. Sies, H.; Stahl, W.; Sevanian, A. Nutritional, dietary and postprandial oxidative stress. J. Nutr. 2005, 135, 969-972. [PubMed]

11. Forcados, G.E.; Chinyere, C.N.; Shu, M.L. Acalypha wilkesiana: Therapeutic and toxic potential. J. Med. Surg. Pathol. 2016, 1, 122. 
12. Alpay, M.; Backman, L.R.F.; Cheng, X.D.; Dukel, M.; Kim, W.J.; Ai, L.B.; Brown, K.D. Oxidative stress shapes breast cancer phenotype through chronic activation of ATM-dependent signaling. Breast Cancer Res. Treat. 2015, 151, 75-87. [CrossRef] [PubMed]

13. Pisoschi, A.M.; Pop, A. The role of antioxidants in the chemistry of oxidative stress: A review. Eur. J. Med. Chem. 2015, 97, 55-74. [CrossRef] [PubMed]

14. Dalle-Donne, I.; Rossi, R.; Colombo, R.; Giustarini, D.; Milzani, A. Biomarkers of oxidative damage in human disease. Clin. Chem. 2006, 52, 601-623. [CrossRef] [PubMed]

15. Agarwal, A.; Aponte-Mellado, A.; Premkumar, B.J.; Shaman, A.; Gupta, S. The effects of oxidative stress on female reproduction: A review. Reprod. Biol. Endocrinol. 2012, 10, 49. [CrossRef] [PubMed]

16. Tangvarasittichai, S. Oxidative stress, insulin resistance, dyslipidemia and type 2 diabetes mellitus. World J. Diabetes 2015, 6, 456-480. [CrossRef] [PubMed]

17. Lee, J.D.; Cai, Q.; Shu, X.O.; Nechuta, S.J. The role of biomarkers of oxidative stress in breast cancer risk and prognosis: A systematic review of the epidemiologic literature. J. Women's Health 2017, 26, 467-482. [CrossRef] [PubMed]

18. Zhang, L.; Li, L.; Gao, G.; Wei, G.; Zheng, Y.; Wang, C.; Gao, N.; Zhao, Y.; Deng, J.; Chen, H. Elevation of GPRC5A expression in colorectal cancer promotes tumor progression through VNN-1 induced oxidative stress. Int. J. Cancer 2017, 140, 2734-2747. [CrossRef] [PubMed]

19. Saijo, H.; Hirohashi, Y.; Torigoe, T.; Horibe, R.; Takaya, A.; Murai, A.; Kubo, T.; Kajiwara, T.; Tanaka, T.; Shionoya, Y.; et al. Plasticity of lung cancer stem-like cells is regulated by the transcription factor HOXA5 that is induced by oxidative stress. Oncotarget 2016, 7, 50043-50056. [CrossRef] [PubMed]

20. Wang, Z.P.; Li, Z.N.; Ye, Y.S.; Xie, L.J.; Li, W. Oxidative stress and liver cancer: Etiology and therapeutic targets. Oxidative Med. Cell. Longev. 2016, 2016, 7891574. [CrossRef] [PubMed]

21. Oh, B.; Figtree, G.; Costa, D.; Eade, T.; Hruby, G.; Lim, S.; Elfiky, A.; Martine, N.; Rosenthal, D.; Clarke, S.; et al. Oxidative stress in prostate cancer patients: A systematic review of case control studies. Prostate Int. 2016, 4, 71-87. [CrossRef] [PubMed]

22. Saed, G.M.; Diamond, M.P.; Fletcher, N.M. Updates of the role of oxidative stress in the pathogenesis of ovarian cancer. Gynecol. Oncol. 2017, 145, 595-602. [CrossRef] [PubMed]

23. Jaroonwitchawan, T.; Chaicharoenaudomrung, N.; Natnkaew, J.; Noisa, P. Curcumin attenuates paraquat-induced cell death in human neuroblastoma cells through modulating oxidative stress and autophagy. Neurosci. Lett. 2017, 636, 40-47. [CrossRef] [PubMed]

24. Forcados, G.E.; James, D.B.; Sallau, A.B.; Muhammad, A.; Mabeta, P. Oxidative stress and carcinogenesis: Potential of phytochemicals in breast cancer therapy. Nutr. Cancer 2017, 69, 365-374. [CrossRef] [PubMed]

25. Matsui, A.; Ikeda, T.; Enomoto, K.; Hosoda, K.; Nakashima, H.; Omae, K.; Watanabe, M.; Hibi, T.; Kitajima, M. Increased formation of oxidative DNA damage, 8-hydroxy-2'-deoxyguanosine, in human breast cancer tissue and its relationship to GSTP1 and COMT genotypes. Cancer Lett. 2000, 151, 87-95. [CrossRef]

26. Sova, H.; Jukkola-Vuorinen, A.; Puistola, U.; Kauppila, S.; Karihtala, P. 8-Hydroxydeoxyguanosine: A new potential independent prognostic factor in breast cancer. Br. J. Cancer 2010, 102, 1018-1023. [CrossRef] [PubMed]

27. Aldini, G.; Dalle-Donne, I.; Facino, R.M.; Milzani, A.; Carini, M. Intervention strategies to inhibit protein carbonylation by lipoxidation-derived reactive carbonyls. Med. Res. Rev. 2007, 27, 817-868. [CrossRef] [PubMed]

28. Skurk, T.; Alberti-Huber, C.; Herder, C.; Hauner, H. Relationship between adipocyte size and adipokine expression and secretion. J. Clin. Endocrinol. Metab. 2007, 92, 1023-1033. [CrossRef] [PubMed]

29. Montezano, A.C.; Dulak-Lis, M.; Tsiropoulou, S.; Harvey, A.; Briones, A.M.; Touyz, R.M. Oxidative stress and human hypertension: Vascular mechanisms, biomarkers, and novel therapies. Can. J. Cardiol. 2015, 31, 631-641. [CrossRef] [PubMed]

30. Wong, W.T.; Tian, X.Y.; Huang, Y. Endothelial dysfunction in diabetes and hypertension: Cross talk in RAS, BMP4, and ROS-dependent COX-2-derived prostanoids. J. Cardiovasc. Pharmacol. 2013, 61, $204-214$. [CrossRef] [PubMed]

31. WHO. Diet, nutrition and the prevention of chronic diseases. In Proceedings of the WHO/FAO Expert Consultation on Diet, Nutrition and the Prevention of Chronic Diseases, Geneva, Switzerland, 28 January-1 February 2002. 
32. Hernanz, R.; Briones, A.M.; Salaices, M.; Alonso, M.J. New roles for old pathways? A circuitous relationship between reactive oxygen species and cyclo-oxygenase in hypertension. Clin. Sci. 2014, 126, 111-121. [CrossRef] [PubMed]

33. Ward, N.C.; Hodgson, J.M.; Puddey, I.B.; Mori, T.A.; Beilin, L.J.; Croft, K.D. Oxidative stress in human hypertension: Association with antihypertensive treatment, gender, nutrition, and lifestyle. Free Radic. Biol. Med. 2004, 36, 226-232. [CrossRef] [PubMed]

34. Houstis, N.; Rosen, E.D.; Lander, E.S. Reactive oxygen species have a causal role in multiple forms of insulin resistance. Nature 2006, 440, 944-948. [CrossRef] [PubMed]

35. Hotamisligil, G.S. Inflammation and metabolic disorders. Nature 2006, 444, 860-867. [CrossRef] [PubMed]

36. Lee, H.-S. Impact of maternal diet on the epigenome during in utero life and the developmental programming of diseases in childhood and adulthood. Nutrients 2015, 7, 9492-9507. [CrossRef] [PubMed]

37. Barker, D.J.; Osmond, C.; Winter, P.; Margetts, B.; Simmonds, S.J. Weight in infancy and death from ischaemic heart disease. Lancet 1989, 334, 577-580. [CrossRef]

38. Barker, D.J. Maternal nutrition, fetal nutrition, and disease in later life. Nutr. J. 1997, 13, 807-813. [CrossRef]

39. Armitage, J.A.; Taylor, P.D.; Poston, L. Experimental models of developmental programming: Consequences of exposure to an energy rich diet during development. J. Physiol. 2005, 565, 3-8. [CrossRef] [PubMed]

40. Gamborg, M.; Byberg, L.; Rasmussen, F.; Andersen, P.K.; Baker, J.L.; Bengtsson, C.; Canoy, D.; Drøyvold, W.; Eriksson, J.G.; Forsén, T. Birth weight and systolic blood pressure in adolescence and adulthood: Meta-regression analysis of sex-and age-specific results from 20 Nordic studies. Am. J. Epidemiol. 2007, 166, 634-645. [CrossRef] [PubMed]

41. Thompson, L.P.; Al-Hasan, Y. Impact of oxidative stress in fetal programming. J. Pregnancy 2012, 2012, 582748. [CrossRef] [PubMed]

42. Aiken, C.E.; Tarry-Adkins, J.L.; Penfold, N.C.; Dearden, L.; Ozanne, S.E. Decreased ovarian reserve, dysregulation of mitochondrial biogenesis, and increased lipid peroxidation in female mouse offspring exposed to an obesogenic maternal diet. FASEB J. 2016, 30, 1548-1556. [CrossRef] [PubMed]

43. Saad, M.I.; Abdelkhalek, T.M.; Haiba, M.M.; Saleh, M.M.; Hanafi, M.Y.; Tawfik, S.H.; Kamel, M.A. Maternal obesity and malnourishment exacerbate perinatal oxidative stress resulting in diabetogenic programming in F1 offspring. J. Endocrinol. Investig. 2016, 39, 643-655. [CrossRef] [PubMed]

44. Fetoui, H.; Garoui, M.; Zeghal, N. Protein restriction in pregnant- and lactating rats-induced oxidative stress and hypohomocysteinaemia in their offspring. J. Anim. Physiol. Anim. Nutr. 2009, 93, 263-270. [CrossRef] [PubMed]

45. Sen, S.; Simmons, R.A. Maternal Antioxidant Supplementation Prevents Adiposity in the Offspring of Western Diet-Fed Rats. Diabetes 2010, 59, 3058-3065. [CrossRef] [PubMed]

46. Mohanty, P.; Hamouda, W.; Garg, R.; Aljada, A.; Ghanim, H.; Dandona, P. Glucose challenge stimulates reactive oxygen species (ROS) generation by leucocytes. J. Clin. Endocrinol. Metab. 2000, 85, 2970-2973. [CrossRef] [PubMed]

47. Mohanty, P.; Ghanim, H.; Hamouda, W.; Aljada, A.; Garg, R.; Dandona, P. Both lipid and protein intakes stimulate increased generation of reactive oxygen species by polymorphonuclear leukocytes and mononuclear cells. Am. J. Clin. Nutr. 2002, 75, 767-772. [PubMed]

48. Aljada, A.; Mohanty, P.; Ghanim, H.; Abdo, T.; Tripathy, D.; Chaudhuri, A.; Dandona, P. Increase in intranuclear nuclear factor kappaB and decrease in inhibitor kappaB in mononuclear cells after a mixed meal: Evidence for a proinflammatory effect. Am. J. Clin. Nutr. 2004, 79, 682-690. [PubMed]

49. Ceriello, A.; Motz, E. Is oxidative stress the pathogenic mechanism underlying insulin resistance, diabetes, and cardiovascular disease? The common soil hypothesis revisited. Arterioscler. Thromb. Vasc. Biol. 2004, 24, 816-823. [CrossRef] [PubMed]

50. Wallace, J.P.; Johnson, B.; Padilla, J.; Mather, K. Postprandial lipaemia, oxidative stress and endothelial function: A review. Int. J. Clin. Pract. 2010, 64, 389-403. [CrossRef] [PubMed]

51. Dandona, P.; Mohanty, P.; Ghanim, H.; Aljada, A.; Browne, R.; Hamouda, W.; Prabhala, A.; Afzal, A.; Garg, R. The suppressive effect of dietary restriction and weight loss in the obese on the generation of reactive oxygen species by leukocytes, lipid peroxidation, and protein carbonylation. J. Clin. Endocrinol. Metab. 2001, 86, 355-362. [CrossRef] [PubMed] 
52. Dandona, P.; Mohanty, P.; Hamouda, W.; Ghanim, H.; Aljada, A.; Garg, R.; Kumar, V. Inhibitory effect of a two day fast on reactive oxygen species (ROS) generation by leucocytes and plasma ortho-tyrosine and meta-tyrosine concentrations. J. Clin. Endocrinol. Metab. 2001, 86, 2899-2902. [CrossRef] [PubMed]

53. Rizza, W.; Veronese, N.; Fontana, L. What are the roles of calorie restriction and diet quality in promoting healthy longevity? Ageing Res. Rev. 2014, 13, 38-45. [CrossRef] [PubMed]

54. Bloomer, R.J.; Fisher-Wellman, K.H. Systemic oxidative stress is increased to a greater degree in young, obese women following consumption of a high fat meal. Oxidative Med. Cell. Longev. 2009, 2, 19-25. [CrossRef]

55. Goto, C.; Nishioka, K.; Umemura, T.; Jitsuiki, D.; Sakagutchi, A.; Kawamura, M.; Chayama, K.; Yoshizumi, M.; Higashi, Y. Acute moderate-intensity exercise induces vasodilation through oxide bioavailiability an increase in nitric in humans. Am. J. Hypertens. 2007, 20, 825-830. [CrossRef] [PubMed]

56. Elosua, R.; Molina, L.; Fito, M.; Arquer, A.; Sanchez-Queseda, J.L.; Covas, M.I.; Ordonez-Llanos, J.; Marrugat, J. Response of oxidative stress biomarkers to a 16-week aerobic physical activity program, and to acute physical activity, in healthy young men and women. Atherosclerosis 2003, 167, 327-334. [CrossRef]

57. Bloomer, R.J.; Ferebee, D.E.; Fisher-Wellman, K.H.; Quindry, J.C.; Schilling, B.K. Postprandial oxidative stress: Influence of sex and exercise training status. Med. Sci. Sports Exerc. 2009, 41, 2111-2119. [CrossRef] [PubMed]

58. Droge, W. Free radicals in the physiological control of cell function. Physiol. Rev. 2002, 82, 47-95. [CrossRef] [PubMed]

59. Uribarri, J.; Stirban, A.; Sander, D.; Cai, W.; Negrean, M.; Buenting, C.E.; Koschinsky, T.; Vlassara, H. Single oral challenge by advanced glycation end products acutely impairs endothelial function in diabetic and nondiabetic subjects. Diabetes Care 2007, 30, 2579-2582. [CrossRef] [PubMed]

60. Diamanti-Kandarakis, E.; Katsikis, I.; Piperi, C.; Alexandraki, K.; Panidis, D. Effect of long-term orlistat treatment on serum levels of advanced glycation end-products in women with polycystic ovary syndrome. Clin. Endocrinol. 2007, 66, 103-109. [CrossRef] [PubMed]

61. Muoio, D.M.; Newgard, C.B. Mechanisms of disease: Molecular and metabolic mechanisms of insulin resistance and $\beta$-cell failure in type 2 diabetes. Nat. Rev. Mol. Cell Biol. 2008, 9, 193-205. [CrossRef] [PubMed]

62. Samuel, V.T.; Liu, Z.X.; Qu, X.; Elder, B.D.; Bilz, S.; Befroy, D.; Romanelli, A.J.; Shulman, G.I. Mechanism of hepatic insulin resistance in non-alcoholic fatty liver disease. J. Biol. Chem. 2004, 279, 32345-32353. [CrossRef] [PubMed]

63. Soardo, G.; Donnini, D.; Domenis, L.; Catena, C.; De Silvestri, D.; Cappello, D.; Dibenedetto, A.; Carnelutti, A.; Bonasia, V.; Pagano, C.; et al. Oxidative stress is activated by free fatty acids in cultured human hepatocytes. Metab. Syndr. Relat. Disord. 2011, 9, 397-401. [CrossRef] [PubMed]

64. Lara-Castro, C.; Garvey, W.T. Intracellular lipid accumulation in liver and muscle and the insulin resistance syndrome. Endocrinol. Metab. Clin. N. Am. 2008, 37, 841-856. [CrossRef] [PubMed]

65. Le Lay, S.; Simard, G.; Martinez, M.C.; Andriantsitohaina, R. Oxidative stress and metabolic pathologies: From an adipocentric point of view. Oxidative Med. Cell. Longev. 2014, 2014, 908539. [CrossRef] [PubMed]

66. Kusminski, C.M.; Scherer, P.E. Mitochondrial dysfunction in white adipose tissue. Trends Endocrinol. Metab. 2012, 23, 435-443. [CrossRef] [PubMed]

67. Mahadev, K.; Motoshima, H.; Wu, X.D.; Ruddy, J.M.; Arnold, R.S.; Cheng, G.J.; Lambeth, J.D.; Goldstein, B.J. The $\mathrm{NAD}(\mathrm{P}) \mathrm{H}$ oxidase homolog Nox4 modulates insulin-stimulated generation of $\mathrm{H}_{2} \mathrm{O}_{2}$ and plays an integral role in insulin signal transduction. Mol. Cell. Biol. 2004, 24, 1844-1854. [CrossRef] [PubMed]

68. Han, C.Y.; Umemoto, T.; Omer, M.; Den Hartigh, L.J.; Chiba, T.; Leboeuf, R.; Buller, C.L.; Sweet, I.R.; Pennathur, S.; Abel, E.D.; et al. NADPH Oxidase-derived reactive oxygen species increases expression of monocyte chemotactic factor genes in cultured adipocytes. J. Biol. Chem. 2012, 287, 10379-10393. [CrossRef] [PubMed]

69. Herieka, M.; Erridge, C. High-fat meal induced postprandial inflammation. Mol. Nutr. Food Res. 2014, 58, 136-146. [CrossRef] [PubMed]

70. Magne, J.; Mariotti, F.; Fischer, R.; Mathe, V.; Tome, D.; Huneau, J.F. Early postprandial low-grade inflammation after high-fat meal in healthy rats: Possible involvement of visceral adipose tissue. J. Nutr. Biochem. 2010, 21, 550-555. [CrossRef] [PubMed]

71. Travers, R.L.; Motta, A.C.; Betts, J.A.; Thompson, D. Adipose tissue metabolic and inflammatory responses to a mixed meal in lean, overweight and obese men. Eur. J. Nutr. 2017, 56, 375-385. [CrossRef] [PubMed] 
72. Cruz-Teno, C.; Perez-Martinez, P.; Delgado-Lista, J.; Yubero-Serrano, E.M.; Garcia-Rios, A.; Marin, C.; Gomez, P.; Jimenez-Gomez, Y.; Camargo, A.; Rodriguez-Cantalejo, F.; et al. Dietary fat modifies the postprandial inflammatory state in subjects with metabolic syndrome: The LIPGENE study. Mol. Nutr. Food Res. 2012, 56, 854-865. [CrossRef] [PubMed]

73. Meneses, M.E.; Camargo, A.; Perez-Martinez, P.; Delgado-Lista, J.; Cruz-Teno, C.; Jimenez-Gomez, Y.; Paniagua, J.A.; Gutierrez-Mariscal, F.M.; Tinahones, F.J.; Vidal-Puig, A.; et al. Postprandial inflammatory response in adipose tissue of patients with metabolic syndrome after the intake of different dietary models. Mol. Nutr. Food Res. 2011, 55, 1759-1770. [CrossRef] [PubMed]

74. Donath, M.Y. Targeting inflammation in the treatment of type 2 diabetes: Time to start. Nat. Rev. Drug Discov. 2014, 13, 465-476. [CrossRef] [PubMed]

75. Furukawa, S.; Fujita, T.; Shimabukuro, M.; Iwaki, M.; Yamada, Y.; Nakajima, Y.; Nakayama, O.; Makishima, M.; Matsuda, M.; Shimomura, I. Increased oxidative stress in obesity and its impact on metabolic syndrome. J. Clin. Investig. 2004, 114, 1752-1761. [CrossRef] [PubMed]

76. Murdolo, G.; Piroddi, M.; Luchetti, F.; Tortoioli, C.; Canonico, B.; Zerbinati, C.; Galli, F.; Iuliano, L. Oxidative stress and lipid peroxidation by-products at the crossroad between adipose organ dysregulation and obesity-linked insulin resistance. Biochimie 2013, 95, 585-594. [CrossRef] [PubMed]

77. Maechler, P.; Jornot, L.; Wollheim, C.B. Hydrogen peroxide alters mitochondrial activation and insulin secretion in pancreatic $\beta$ cells. J. Biol. Chem. 1999, 274, 27905-27913. [CrossRef] [PubMed]

78. Tiedge, M.; Lortz, S.; Drinkgern, J.; Lenzen, S. Relation between antioxidant enzyme gene expression and antioxidative defense status of insulin-producing cells. Diabetes 1997, 46, 1733-1742. [CrossRef] [PubMed]

79. Jacqueminet, S.; Briaud, I.; Rouault, C.; Reach, G.; Poitout, V. Inhibition of insulin gene expression by long-term exposure of pancreatic $\beta$ cells to palmitate is dependent on the presence of a stimulatory glucose concentration. Metab. Clin. Exp. 2000, 49, 532-536. [CrossRef]

80. Sakai, K.; Matsumoto, K.; Nishikawa, T.; Suefuji, M.; Nakamaru, K.; Hirashima, Y.; Kawashima, J.; Shirotani, T.; Ichinose, K.; Brownlee, M.; et al. Mitochondrial reactive oxygen species reduce insulin secretion by pancreatic $\beta$-cells. Biochem. Biophys. Res. Commun. 2003, 300, 216-222. [CrossRef]

81. Nowotny, K.; Jung, T.; Hohn, A.; Weber, D.; Grune, T. Advanced glycation end products and oxidative stress in type 2 diabetes mellitus. Biomolecules 2015, 5, 194-222. [CrossRef] [PubMed]

82. DeFronzo, R.A.; Gunnarsson, R.; Bjorkman, O.; Olsson, M.; Wahren, J. Effects of insulin on peripheral and splanchnic glucose metabolism in noninsulin-dependent (type II) diabetes mellitus. J. Clin. Investig. 1985, 76, 149-155. [CrossRef] [PubMed]

83. Dimitriadis, G.; Mitrou, P.; Lambadiari, V.; Maratou, E.; Raptis, S.A. Insulin effects in muscle and adipose tissue. Diabetes Res. Clin. Pract. 2011, 93, S52-S59. [CrossRef]

84. Galgani, J.E.; Moro, C.; Ravussin, E. Metabolic flexibility and insulin resistance. Am. J. Physiol. Endocrinol. Metab. 2008, 295, E1009-E1017. [CrossRef] [PubMed]

85. Corpeleijn, E.; Saris, W.H.M.; Blaak, E.E. Metabolic flexibility in the development of insulin resistance and type 2 diabetes: Effects of lifestyle. Obes. Rev. 2009, 10, 178-193. [CrossRef] [PubMed]

86. Pagel-Langenickel, I.; Bao, J.J.; Pang, L.Y.; Sack, M.N. The role of mitochondria in the pathophysiology of skeletal muscle insulin resistance. Endocr. Rev. 2010, 31, 25-51. [CrossRef] [PubMed]

87. Heilbronn, L.K.; de Jonge, L.; Frisard, M.I.; DeLany, J.P.; Larson-Meyer, D.E.; Rood, J.; Nguyen, T.; Martin, C.K.; Volaufova, J.; Most, M.M.; et al. Effect of 6-month calorie restriction on biomarkers of longevity, metabolic adaptation, and oxidative stress in overweight individuals: A randomized controlled trial. J. Am. Med. Assoc. 2006, 295, 1539-1548. [CrossRef] [PubMed]

88. Ceriello, A.; Esposito, K.; La Sala, L.; Pujadas, G.; De Nigris, V.; Testa, R.; Bucciarelli, L.; Rondinelli, M.; Genovese, $\mathrm{S}$. The protective effect of the Mediterranean diet on endothelial resistance to GLP-1 in type 2 diabetes: A preliminary report. Cardiovasc. Diabetol. 2014, 13, 140. [CrossRef] [PubMed]

89. Vineis, P.; Wild, C.P. Global cancer patterns: Causes and prevention. Lancet 2014, 383, 549-557. [CrossRef]

90. World Cancer Research Fund/American Institute for Cancer Research. Food, Nutrition, Physical Activity, and the Prevention of Cancer: A Global Perspective; American Institute for Cancer Research: Washington, DC, USA, 2007.

91. World Cancer Research Fund/American Institute for Cancer Research. Breast Cancer 2010 Report: Food, Nutrition, Physical Activity, and the Prevention of Breast Cancer; American Institute for Cancer Research: Washington, DC, USA, 2010. 
92. World Cancer Research Fund/American Institute for Cancer Research. Colorectal Cancer 2011 Report: Food, Nutrition, Physical Activity, and the Prevention of Colorectal Cancer; American Institute for Cancer Research: Washington, DC, USA, 2011.

93. World Cancer Research Fund/American Institute for Cancer Research. Pancreatic Cancer 2012 Report: Food, Nutrition, Physical Activity, and the Prevention of Pancreatic Cancer; American Institute for Cancer Research: Washington, DC, USA, 2012.

94. World Cancer Research Fund/American Institute for Cancer Research. Endometrial Cancer 2013 Report: Food, Nutrition, Physical Activity, and the Prevention of Endometrial Cancer; American Institute for Cancer Research: Washington, DC, USA, 2013.

95. World Cancer Research Fund/American Institute for Cancer Research. Ovarian Cancer 2014 Report: Food, Nutrition, Physical Activity, and the Prevention of Ovarian Cancer; American Institute for Cancer Research: Washington, DC, USA, 2014.

96. Ames, B.N.; Wakimoto, P. Are vitamin and mineral deficiencies a major cancer risk? Nat. Rev. Cancer 2002, 2, 694-704. [CrossRef] [PubMed]

97. Brash, D.E.; Havre, P. New careers for antioxidants. Proc. Natl. Acad. Sci. USA 2002, 99, 13969-13971. [CrossRef] [PubMed]

98. Mathers, J.; Coxhead, J.; Tyson, J. Nutrition and DNA repair-potential molecular mechanisms of action. Curr. Cancer Drug Targets 2007, 7, 425-431. [CrossRef] [PubMed]

99. Shimada, T.; Fujii-Kuriyama, Y. Metabolic activation of polycyclic aromatic hydrocarbons to carcinogens by cytochromes P450 1A1 and 1B1. Cancer Sci. 2004, 95, 1-6. [CrossRef] [PubMed]

100. Shimada, T.; Inoue, K.; Suzuki, Y.; Kawai, T.; Azuma, E.; Nakajima, T.; Shindo, M.; Kurose, K.; Sugie, A.; Yamagishi, Y.; et al. Arylhydrocarbon receptor-dependent induction of liver and lung cytochromes P450 1A1, $1 \mathrm{~A} 2$, and $1 \mathrm{~B} 1$ by polycyclic aromatic hydrocarbons and polychlorinated biphenyls in genetically engineered C57BL/6J mice. Carcinogenesis 2002, 23, 1199-1207. [CrossRef] [PubMed]

101. Puga, A.; Ma, C.; Marlowe, J.L. The aryl hydrocarbon receptor cross-talks with multiple signal transduction pathways. Biochem. Pharmacol. 2009, 77, 713-722. [CrossRef] [PubMed]

102. Androutsopoulos, V.P.; Tsatsakis, A.M.; Spandidos, D.A. Cytochrome P450 CYP1A1: Wider roles in cancer progression and prevention. BMC Cancer 2009, 9, 187. [CrossRef] [PubMed]

103. Baan, R.; Straif, K.; Grosse, Y.; Secretan, B.; El Ghissassi, F.; Bouvard, V.; Altieri, A.; Cogliano, V.; WHO International Agency for Research on Cancer Monograph Working Group. Carcinogenicity of alcoholic beverages. Lancet Oncol. 2007, 8, 292-293. [CrossRef]

104. Savolainen, V.; Liesto, K.; Männikkö, A.; Penttilä, A.; Karhunen, P. Alcohol consumption and alcoholic liver disease: Evidence of a threshold level of effects of ethanol. Alcohol. Clin. Exp. Res. 1993, 17, 1112-1117. [CrossRef] [PubMed]

105. Wu, D.; Cederbaum, A.I. Oxidative stress and alcoholic liver disease. Semin. Liver Dis. 2009, 29, $141-154$. [CrossRef] [PubMed]

106. Sabitha, K.; Venugopal, B.; Rafi, M.; Ramana, K. Role of antioxidant enzymes in glucose and lipid metabolism in association with obesityand type 2 diabetes. Am. J. Med. Sci. Med. 2014, 2, 21-24. [CrossRef]

107. Fang, J.-L.; Vaca, C.E. Detection of DNA adducts of acetaldehyde in peripheral white blood cells of alcohol abusers. Carcinogenesis 1997, 18, 627-632. [CrossRef] [PubMed]

108. Praud, D.; Rota, M.; Rehm, J.; Shield, K.; Zatoński, W.; Hashibe, M.; La Vecchia, C.; Boffetta, P. Cancer incidence and mortality attributable to alcohol consumption. Int. J. Cancer 2016, 138, 1380-1387. [CrossRef] [PubMed]

109. Gavin, D.P.; Kusumo, H.; Zhang, H.; Guidotti, A.; Pandey, S.C. Role of Growth arrest and DNA damage-inducible, $\beta$ in alcohol-drinking behaviors. Alcohol. Clin. Exp. Res. 2016, 40, 263-272. [CrossRef] [PubMed]

110. Chuang, S.C.; La Vecchia, C.; Boffetta, P. Liver cancer: Descriptive epidemiology and risk factors other than HBV and HCV infection. Cancer Lett. 2009, 286, 9-14. [CrossRef] [PubMed]

111. Druesne-Pecollo, N.; Tehard, B.; Mallet, Y.; Gerber, M.; Norat, T.; Hercberg, S.; Latino-Martel, P. Alcohol and genetic polymorphisms: Effect on risk of alcohol-related cancer. Lancet Oncol. 2009, 10, 173-180. [CrossRef]

112. Deshpande, N.; Kandi, S.; Muddeshwar, M.; Ramana, K.V. Effect of alcohol consumption and oxidative stress and its role in dna damage. Am. J. Biomed. Res. 2014, 2, 7-10. [CrossRef] 
113. Wang, Y.; Millonig, G.; Nair, J.; Patsenker, E.; Stickel, F.; Mueller, S.; Bartsch, H.; Seitz, H.K. Ethanol-induced cytochrome P4502E1 causes carcinogenic etheno-DNA lesions in alcoholic liver disease. Hepatology 2009, 50, 453-461. [CrossRef] [PubMed]

114. Brooks, P.J.; Zakhari, S. Moderate alcohol consumption and breast cancer in women: From epidemiology to mechanisms and interventions. Alcohol. Clin. Exp. Res. 2013, 37, 23-30. [CrossRef] [PubMed]

115. Suzuki, R.; Orsini, N.; Mignone, L.; Saji, S.; Wolk, A. Alcohol intake and risk of breast cancer defined by estrogen and progesterone receptor status-A meta-analysis of epidemiological studies. Int. J. Cancer 2008, 122, 1832-1841. [CrossRef] [PubMed]

116. Zuccolo, L.; Lewis, S.J.; Donovan, J.L.; Hamdy, F.C.; Neal, D.E.; Smith, G.D. Alcohol consumption and PSA-detected prostate cancer risk-A case-control nested in the ProtecT study. Int. J. Cancer 2013, 132, 2176-2185. [CrossRef] [PubMed]

117. Sawada, N.; Inoue, M.; Iwasaki, M.; Sasazuki, S.; Yamaji, T.; Shimazu, T.; Tsugane, S. Alcohol and smoking and subsequent risk of prostate cancer in Japanese men: The Japan Public Health Center-based prospective study. Int. J. Cancer 2014, 134, 971-978. [CrossRef] [PubMed]

118. Watters, J.L.; Park, Y.; Hollenbeck, A.; Schatzkin, A.; Albanes, D. Alcoholic beverages and prostate cancer in a prospective US cohort study. Am. J. Epidemiol. 2010, 172, 773-780. [CrossRef] [PubMed]

119. Chao, C.; Haque, R.; Van Den Eeden, S.K.; Caan, B.J.; Poon, K.Y.; Quinn, V.P. Red wine consumption and risk of prostate cancer: The California men's health study. Int. J. Cancer 2010, 126, 171-179. [CrossRef] [PubMed]

120. Breslow, R.A.; Chen, C.M.; Graubard, B.I.; Mukamal, K.J. Prospective study of alcohol consumption quantity and frequency and cancer-specific mortality in the US population. Am. J. Epidemiol. 2011, 174, 1044-1053. [CrossRef] [PubMed]

121. Middleton Fillmore, K.; Chikritzhs, T.; Stockwell, T.; Bostrom, A.; Pascal, R. Alcohol use and prostate cancer: A meta-analysis. Mol. Nutr. Food Res. 2009, 53, 240-255. [CrossRef] [PubMed]

122. Rota, M.; Scotti, L.; Turati, F.; Tramacere, I.; Islami, F.; Bellocco, R.; Negri, E.; Corrao, G.; Boffetta, P.; La Vecchia, C. Alcohol consumption and prostate cancer risk: A meta-analysis of the dose-risk relation. Eur. J. Cancer Prev. 2012, 21, 350-359. [CrossRef] [PubMed]

123. Shahedi, K.; Pandol, S.J.; Hu, R. Oxidative stress and alcoholic pancreatitis. J. Gastroenterol. Hepatol. Res. 2013, 2, 335-342.

124. Kandi, S.; Deshpande, N.; Pinnelli, V.B.K.; Devaki, R.; Rao, P.; Ramana, K. Alcoholism and its role in the development of oxidative stress and DNA damage: An Insight. Am. J. Med. Sci. Med. 2014, 2, 64-66. [CrossRef]

125. Cunningham, C.C.; Bailey, S.M. Ethanol consumption and liver mitochondria function. Neurosignals 2001, 10, 271-282. [CrossRef]

126. Arranz, S.; Chiva-Blanch, G.; Valderas-Martínez, P.; Medina-Remón, A.; Lamuela-Raventós, R.M.; Estruch, R. Wine, beer, alcohol and polyphenols on cardiovascular disease and cancer. Nutrients 2012, 4, 759-781. [CrossRef] [PubMed]

127. Varela-Rey, M.; Woodhoo, A.; Martinez-Chantar, M.-L.; Mato, J.M.; Lu, S.C. Alcohol, DNA methylation, and cancer. Alcohol Res. 2013, 35, 25. [PubMed]

128. Wei-Chuan, T.; Yi-Heng, L.; Chih-Chan, L.; Ting-Hsing, C.; Jyh-Hong, C. Effects of oxidative stress on endothelial function after a high-fat meal. Clin. Sci. 2004, 106, 315-319.

129. Gregersen, S.; Samocha-Bonet, D.; Heilbronn, L.; Campbell, L. Inflammatory and oxidative stress responses to high-carbohydrate and high-fat meals in healthy humans. J. Nutr. Metab. 2012, 2012, 238056. [CrossRef] [PubMed]

130. Michels, K.B.; Mohllajee, A.P.; Roset-Bahmanyar, E.; Beehler, G.P.; Moysich, K.B. Diet and breast cancer: A review of the prospective observational studies. Cancer 2007, 109, 2712-2749. [CrossRef] [PubMed]

131. Shikany, J.M.; Redden, D.T.; Neuhouser, M.L.; Chlebowski, R.T.; Rohan, T.E.; Simon, M.S.; Liu, S.; Lane, D.S.; Tinker, L. Dietary glycemic load, glycemic index, and carbohydrate and risk of breast cancer in the Women's Health Initiative. Nutr. Cancer 2011, 63, 899-907. [CrossRef] [PubMed]

132. Amador-Licona, N.; Díaz-Murillo, T.A.; Gabriel-Ortiz, G.; Pacheco-Moises, F.P.; Pereyra-Nobara, T.A.; Guízar-Mendoza, J.M.; Barbosa-Sabanero, G.; Orozco-Aviña, G.; Moreno-Martínez, S.C.; Luna-Montalbán, R. Omega 3 fatty acids supplementation and oxidative stress in HIV-seropositive patients. A clinical trial. PLoS ONE 2016, 11, e0151637. [CrossRef] [PubMed] 
133. Assies, J.; Mocking, R.J.; Lok, A.; Ruhé, H.G.; Pouwer, F.; Schene, A.H. Effects of oxidative stress on fatty acid-and one-carbon-metabolism in psychiatric and cardiovascular disease comorbidity. Acta Psychiatr. Scand. 2014, 130, 163-180. [CrossRef] [PubMed]

134. Bieniek, J.; Childress, C.; Swatski, M.D.; Yang, W. COX-2 inhibitors arrest prostate cancer cell cycle progression by down/regulation of kinetochore/ centromere proteins. Prostate 2014, 74, 999-1011. [CrossRef] [PubMed]

135. Liu, J.; Hu, S.; Cui, Y.; Sun, M.-K.; Xie, F.; Zhang, Q.; Jin, J. Saturated fatty acids up-regulate COX-2 expression in prostate epithelial cells via toll-like receptor 4/NF-kB signaling. Inflammation 2014, 37, 467-477. [CrossRef] [PubMed]

136. Gu, Z.N.; Suburu, J.; Chen, H.Q.; Chen, Y.Q. Mechanisms of Omega-3 polyunsaturated fatty acids in prostate cancer prevention. Biomed. Res. Int. 2013, 2013, 824563. [CrossRef] [PubMed]

137. Larsson, S.C.; Kumlin, M.; Ingelman-Sundberg, M.; Wolk, A. Dietary long-chain n-3 fatty acids for the prevention of cancer: A review of potential mechanisms. Am. J. Clin. Nutr. 2004, 79, 935-945. [PubMed]

138. Sánchez, D.; Quiñones, M.; Moulay, L.; Muguerza, B.; Miguel, M.; Aleixandre, A. Soluble fiber-enriched diets improve inflammation and oxidative stress biomarkers in Zucker fatty rats. Pharmacol. Res. 2011, 64, 31-35. [CrossRef] [PubMed]

139. Nance, S.A.; A'ja, V.D.; Gwathmey, T.M.; Hairston, K.G. Soluble dietary fiber in obesity-associated inflammation and oxidative stress in African American women. FASEB J. 2017, 31, 434.2.

140. Belobrajdic, D.P.; Lam, Y.Y.; Mano, M.; Wittert, G.A.; Bird, A.R. Cereal based diets modulate some markers of oxidative stress and inflammation in lean and obese Zucker rats. Nutr. Metab. 2011, 8, 27. [CrossRef] [PubMed]

141. Diniz, Y.S.; Cicogna, A.C.; Padovani, C.R.; Silva, M.D.; Faine, L.A.; Galhardi, C.M.; Rodrigues, H.G.; Novelli, E.L. Dietary restriction and fibre supplementation: Oxidative stress and metabolic shifting for cardiac health. Can. J. Physiol. Pharmacol. 2003, 81, 1042-1048. [CrossRef] [PubMed]

142. Dong, J.Y.; He, K.; Wang, P.Y.; Qin, L.Q. Dietary fiber intake and risk of breast cancer: A meta-analysis of prospective cohort studies. Am. J. Clin. Nutr. 2011, 94, 900-905. [CrossRef] [PubMed]

143. Aune, D.; Chan, D.S.M.; Greenwood, D.C.; Vieira, A.R.; Rosenblatt, D.A.N.; Vieira, R.; Norat, T. Dietary fiber and breast cancer risk: A systematic review and meta-analysis of prospective studies. Ann. Oncol. 2012, 23, 1394-1402. [CrossRef] [PubMed]

144. Romaneiro, S.; Parekh, N. Dietary fiber intake and colorectal cancer risk: Weighing the evidence from epidemiologic studies. Top. Clin. Nutr. 2012, 27, 41-47. [CrossRef]

145. Lottenberg, A.M.P.; Fan, P.L.T.; Buonacorso, V. Effects of dietary fiber intake on inflammation in chronic diseases. Einstein 2010, 8, 254-258. [CrossRef] [PubMed]

146. Mukai, R.; Terao, J. Role of dietary flavonoids in oxidative stress and prevention of muscle atrophy. J. Phys. Fit. Sport Med. 2013, 2, 385-392. [CrossRef]

147. Costa Marques, T.H.; Santos De Melo, C.H.; De Carvalho, F.; Rusbene, B.; Costa, L.M.; De Souza, A.A.; David, J.M.; De Lima David, J.P.; De Freitas, R.M. Phytochemical profile and qualification of biological activity of an isolated fraction of Bellis perennis. Biol. Res. 2013, 46, 231-238. [CrossRef] [PubMed]

148. Yokomizo, A.; Moriwaki, M. Effects of uptake of flavonoids on oxidative stress induced by hydrogen peroxide in human intestinal Caco-2 cells. Biosci. Biotechnol. Biochem. 2006, 70, 1317-1324. [CrossRef] [PubMed]

149. Zhang, H.Y.; Cui, J.; Zhang, Y.; Wang, Z.L.; Chong, T.; Wang, Z.M. Isoflavones and prostate cancer: A review of some critical issues. Chin. Med. J. 2016, 129, 341-347. [PubMed]

150. Tse, G.; Eslick, G.D. Soy and isoflavone consumption and risk of gastrointestinal cancer: A systematic review and meta-analysis. Eur. J. Nutr. 2016, 55, 63-73. [CrossRef] [PubMed]

151. Nagata, C. Factors to consider in the association between soy isoflavone intake and breast cancer risk. J. Epidemiol. 2010, 20, 83-89. [CrossRef] [PubMed]

152. Stubert, J.; Gerber, B. Isoflavones-Mechanism of action and impact on breast cancer risk. Breast Care 2009, 4, 22-29. [CrossRef] [PubMed]

153. Kobayashi, T.; Nakata, T.; Kuzumaki, T. Effect of flavonoids on cell cycle progression in prostate cancer cells. Cancer Lett. 2002, 176, 17-23. [CrossRef]

154. Ramos, S. Effects of dietary flavonoids on apoptotic pathways related to cancer chemoprevention. J. Nutr. Biochem. 2007, 18, 427-442. [CrossRef] [PubMed] 
155. Petzke, K.J.; Elsner, A.; Proll, J.; Thielecke, F.; Metges, C.C. Long-term high protein intake does not increase oxidative stress in rats. J. Nutr. 2000, 130, 2889-2896. [PubMed]

156. Ezraty, B.; Gennaris, A.; Barras, F.; Collet, J.-F. Oxidative stress, protein damage and repair in bacteria. Nat. Rev. Microbiol. 2017, 15, 385-396. [CrossRef] [PubMed]

157. Levine, M.E.; Suarez, J.A.; Brandhorst, S.; Balasubramanian, P.; Cheng, C.-W.; Madia, F.; Fontana, L.; Mirisola, M.G.; Guevara-Aguirre, J.; Wan, J. Low protein intake is associated with a major reduction in IGF-1, cancer, and overall mortality in the 65 and younger but not older population. Cell Metab. 2014, 19, 407-417. [CrossRef] [PubMed]

158. Alexander, D.D.; Weed, D.L.; Miller, P.E.; Mohamed, M.A. Red meat and colorectal cancer: A quantitative update on the state of the epidemiologic science. J. Am. Coll. Nutr. 2015, 34, 521-543. [CrossRef] [PubMed]

159. Olson, J.A. Carotenoids and Vitamin A: An Overview. In Lipid-Soluble Antioxidants: Biochemistry and Clinical Applications; Ong, A.S.H., Packer, L., Eds.; Birkhäuser Basel: Basel, Switzerland, 1992; pp. 178-192.

160. Meydani, M. Protective role of dietary vitamin E on oxidative stress in aging. Age 1992, 15, 89-93. [CrossRef]

161. Huang, X.Y.; Gao, Y.S.; Zhi, X.S.; Ta, N.; Jiang, H.; Zheng, J.M. Association between vitamin A, retinol and carotenoid intake and pancreatic cancer risk: Evidence from epidemiologic studies. Sci. Rep. 2016, 6, 38936. [CrossRef] [PubMed]

162. Gong, Z.; Holly, E.A.; Bracci, P.M. Intake of folate, vitamins B6, B12 and methionine and risk of pancreatic cancer in a large population-based case-control study. Cancer Causes Control 2009, 20, 1317-1325. [CrossRef] [PubMed]

163. Fan, H.; Kou, J.T.; Han, D.D.; Li, P.; Zhang, D.; Wu, Q.; He, Q. Association between vitamin C intake and the risk of pancreatic cancer: A meta-analysis of observational studies. Sci. Rep. 2015, 5, 13973. [CrossRef] [PubMed]

164. Cadeau, C.; Fournier, A.; Mesrine, S.; Clavel-Chapelon, F.; Fagherazzi, G.; Boutron-Ruault, M.C. Postmenopausal breast cancer risk and interactions between body mass index, menopausal hormone therapy use, and vitamin D supplementation: Evidence from the E3N cohort. Int. J. Cancer 2016, 139, 2193-2200. [CrossRef] [PubMed]

165. Peng, L.J.; Liu, X.D.; Lu, Q.; Tang, T.Q.; Yang, Z.Y. Vitamin E intake and pancreatic cancer risk: A meta-analysis of observational studies. Med. Sci. Monit. 2015, 21, 1249-1255. [PubMed]

166. Garland, C.F.; Garland, F.C.; Gorham, E.D.; Lipkin, M.; Newmark, H.; Mohr, S.B.; Holick, M.F. The role of vitamin D in cancer prevention. Am. J. Public Health 2006, 96, 252-261. [CrossRef] [PubMed]

167. Brand-Miller, J.C. Postprandial glycemia, glycemic index, and the prevention of type 2 diabetes. Am. J. Clin. Nutr. 2004, 80, 243-244. [PubMed]

168. Turati, F.; Galeone, C.; Gandini, S.; Augustin, L.S.; Jenkins, D.J.; Pelucchi, C.; La Vecchia, C. High glycemic index and glycemic load are associated with moderately increased cancer risk. Mol. Nutr. Food Res. 2015, 59, 1384-1394. [CrossRef] [PubMed]

169. Choi, Y.; Giovannucci, E.; Lee, J.E. Glycaemic index and glycaemic load in relation to risk of diabetes-related cancers: A meta-analysis. Br. J. Nutr. 2012, 108, 1934-1947. [CrossRef] [PubMed]

170. Ye, Y.; Wu, Y.; Xu, J.; Ding, K.; Shan, X.; Xia, D. Association between dietary carbohydrate intake, glycemic index and glycemic load, and risk of gastric cancer. Eur. J. Nutr. 2017, 56, 1169-1177. [CrossRef] [PubMed]

171. Melkonian, S.C.; Daniel, C.R.; Ye, Y.; Pierzynski, J.A.; Roth, J.A.; Wu, X. Glycemic index, glycemic load, and lung cancer risk in non-hispanic whites. Cancer Epidemiol. Biomark. Prev. 2016, 25, 532-539. [CrossRef] [PubMed]

172. Gordin, D.; Groop, P.-H. Aspects of Hyperglycemia Contribution to arterial stiffness and cardiovascular complications in patients with type 1 diabetes. J. Diabetes Sci. Technol. 2016, 10, 1059-1064. [CrossRef] [PubMed]

173. Ceriello, A. The post-prandial state and cardiovascular disease: Relevance to diabetes mellitus. Diabetes Metab. Res. Rev. 2000, 16, 125-132. [CrossRef]

174. Vanessa Fiorentino, T.; Prioletta, A.; Zuo, P.; Folli, F. Hyperglycemia-induced oxidative stress and its role in diabetes mellitus related cardiovascular diseases. Curr. Pharm. Des. 2013, 19, 5695-5703. [CrossRef]

175. Tang, W.H.; Martin, K.A.; Hwa, J. Aldose reductase, oxidative stress, and diabetic mellitus. Front. Pharmacol. 2012, 3, 87. [CrossRef] [PubMed]

176. Hu, Y.; Block, G.; Norkus, E.P.; Morrow, J.D.; Dietrich, M.; Hudes, M. Relations of glycemic index and glycemic load with plasma oxidative stress markers. Am. J. Clin. Nutr. 2006, 84, 70-76. [PubMed] 
177. Bajaj, S.; Khan, A. Antioxidants and diabetes. Indian J. Endocrinol. Metab. 2012, 16, S267-S271. [PubMed]

178. Choi, S.-W.; Benzie, I.F.; Ma, S.-W.; Strain, J.; Hannigan, B.M. Acute hyperglycemia and oxidative stress: Direct cause and effect? Free Radic. Biol. Med. 2008, 44, 1217-1231. [CrossRef] [PubMed]

179. De Kreutzenberg, S.V.; Fadini, G.P.; Boscari, F.; Rossi, E.; Guerra, S.; Sparacino, G.; Cobelli, C.; Ceolotto, G.; Bottero, M.; Avogaro, A. Impaired hemodynamic response to meal intake in insulin-resistant subjects: An impedance cardiography approach. Am. J. Clin. Nutr. 2011, 93, 926-933. [CrossRef] [PubMed]

180. Romieu, I.; Ferrari, P.; Rinaldi, S.; Slimani, N.; Jenab, M.; Olsen, A.; Tjonneland, A.; Overvad, K.; Boutron-Ruault, M.-C.; Lajous, M. Dietary glycemic index and glycemic load and breast cancer risk in the European Prospective Investigation into Cancer and Nutrition (EPIC). Am. J. Clin. Nutr. 2012, 96, 345-355. [CrossRef] [PubMed]

181. Wirfalt, E.; McTaggart, A.; Pala, V.; Gullberg, B.; Frasca, G.; Panico, S.; Bueno-de-Mesquita, H.B.; Peeters, P.H.; Engeset, D.; Skeie, G.; et al. Food sources of carbohydrates in a European cohort of adults. Public Health Nutr. 2002, 5, 1197-1215. [CrossRef] [PubMed]

182. O'Neil, C.E.; Keast, D.R.; Fulgoni, V.L.; Nicklas, T.A. Food sources of energy and nutrients among adults in the US: NHANES 2003-2006. Nutrients 2012, 4, 2097-2120. [CrossRef] [PubMed]

183. Varela-López, A.; Quiles, J.L.; Cordero, M.; Giampieri, F.; Bullón, P. Oxidative stress and dietary fat type in relation to periodontal disease. Antioxidants 2015, 4, 322-344. [CrossRef] [PubMed]

184. Guéraud, F.; Taché, S.; Steghens, J.-P.; Milkovic, L.; Borovic-Sunjic, S.; Zarkovic, N.; Gaultier, E.; Naud, N.; Héliès-Toussaint, C.; Pierre, F. Dietary polyunsaturated fatty acids and heme iron induce oxidative stress biomarkers and a cancer promoting environment in the colon of rats. Free Radic. Biol. Med. 2015, 83, 192-200. [CrossRef] [PubMed]

185. Ruiz, R.B.; Hernandez, P.S. Diet and cancer: Risk factors and epidemiological evidence. Maturitas 2014, 77, 202-208. [CrossRef] [PubMed]

186. Dinwiddie, M.T.; Terry, P.D.; Whelan, J.; Patzer, R.E. Omega-3 fatty acid consumption and prostate cancer: A review of exposure measures and results of epidemiological studies. J. Am. Coll. Nutr. 2016, 35, 452-468. [CrossRef] [PubMed]

187. Mocellin, M.C.; Camargo, C.Q.; Nunes, E.A.; Fiates, G.M.R.; Trindade, E.B.S.M. A systematic review and meta-analysis of the n-3 polyunsaturated fatty acids effects on inflammatory markers in colorectal cancer. Clin. Nutr. 2016, 35, 359-369. [CrossRef] [PubMed]

188. Bassett, J.K.; Hodge, A.M.; English, D.R.; MacInnis, R.J.; Giles, G.G. Plasma phospholipids fatty acids, dietary fatty acids, and breast cancer risk. Cancer Causes Control 2016, 27, 759-773. [CrossRef] [PubMed]

189. MacLean, C.H.; Newberry, S.J.; Mojica, W.A.; Khanna, P.; Issa, A.M.; Suttorp, M.J.; Lim, Y.W.; Traina, S.B.; Hilton, L.; Garland, R.; et al. Effects of omega-3 fatty acids on cancer risk-A systematic review. JAMA J. Am. Med. Assoc. 2006, 295, 403-415. [CrossRef] [PubMed]

190. Chan, J.M.; Gann, P.H.; Giovannucci, E.L. Role of diet in prostate cancer development and progression. J. Clin. Oncol. 2005, 23, 8152-8160. [CrossRef] [PubMed]

191. Eser, P.O.; Vanden Heuvel, J.P.; Araujo, J.; Thompson, J.T. Marine-and plant-derived Omega-3 fatty acids differentially regulate prostate cancer cell proliferation. Mol. Clin. Oncol. 2013, 1, 444-452. [PubMed]

192. McCarty, M.F.; Lavie, C.J.; O'Keefe, J.H. Omega-3 and prostate cancer: Examining the pertinent evidence. Mayo Clin. Proc. 2014, 89, 444. [CrossRef] [PubMed]

193. Gao, Z.; Zhang, H.; Liu, J.; Lau, C.W.; Liu, P.; Chen, Z.Y.; Lee, H.K.; Tipoe, G.L.; Ho, H.M.; Yao, X. Cyclooxygenase-2-dependent oxidative stress mediates palmitate-induced impairment of endothelium-dependent relaxations in mouse arteries. Biochem. Pharmacol. 2014, 91, 474-482. [CrossRef] [PubMed]

194. Hori, S.; Butler, E.; McLoughlin, J. Prostate cancer and diet: Food for thought? BJU Int. 2011, 107, 1348-1359. [CrossRef] [PubMed]

195. Shapira, N. Nutritional approach to sun protection: A suggested complement to external strategies. Nutr. Rev. 2010, 68, 75-86. [CrossRef] [PubMed]

196. Barone, M.; Lofano, K.; De Tullio, N.; Licinio, R.; Albano, F.; Di Leo, A. Dietary, endocrine, and metabolic factors in the development of colorectal cancer. J. Gastrointest. Cancer 2012, 43, 13-19. [CrossRef] [PubMed]

197. Chua, M.E.; Sio, M.C.; Sorongon, M.C.; Dy, J.S. Relationship of dietary intake of omega-3 and omega-6 Fatty acids with risk of prostate cancer development: A meta-analysis of prospective studies and review of literature. Prostate Cancer 2012, 2012, 826254. [CrossRef] [PubMed] 
198. Szymanski, K.M.; Wheeler, D.C.; Mucci, L.A. Fish consumption and prostate cancer risk: A review and meta-analysis. Am. J. Clin. Nutr. 2010, 92, 1223-1233. [CrossRef] [PubMed]

199. Aune, D.; Chan, D.S.; Lau, R.; Vieira, R.; Greenwood, D.C.; Kampman, E.; Norat, T. Dietary fibre, whole grains, and risk of colorectal cancer: Systematic review and dose-response meta-analysis of prospective studies. BMJ 2011, 343, d6617. [CrossRef] [PubMed]

200. Mileo, A.M.; Miccadei, S. Polyphenols as modulator of oxidative stress in cancer disease: New therapeutic strategies. Oxidative Med. Cell. Longev. 2016, 2016, 6475624. [CrossRef] [PubMed]

201. Luo, K.-W.; Ko, C.-H.; Yue, G.G.-L.; Lee, J.K.-M.; Li, K.-K.; Lee, M.; Li, G.; Fung, K.-P.; Leung, P.-C.; Bik-San Lau, C. Green tea (Camellia sinensis) extract inhibits both the metastasis and osteolytic components of mammary cancer 4T1 lesions in mice. J. Nutr. Biochem. 2014, 25, 395-403. [CrossRef] [PubMed]

202. Norat, T.; Aune, D.; Chan, D.; Romaguera, D. Fruits and vegetables: Updating the epidemiologic evidence for the WCRF/AICR lifestyle recommendations for cancer prevention. In Advances in Nutrition and Cancer; Springer: Berlin, Germany, 2014; pp. 35-50.

203. Willcox, J.K.; Ash, S.L.; Catignani, G.L. Antioxidants and prevention of chronic disease. Crit. Rev. Food Sci. Nutr. 2004, 44, 275-295. [CrossRef] [PubMed]

204. Hussain, T.; Tan, B.; Yin, Y.; Blachier, F.; Tossou, M.C.B.; Rahu, N. Oxidative stress and inflammation: What polyphenols can do for us? Oxidative Med. Cell. Longev. 2016, 2016, 7432797. [CrossRef] [PubMed]

205. De Souza, P.L.; Russell, P.J.; Kearsley, J.H.; Howes, L.G. Clinical pharmacology of isoflavones and its relevance for potential prevention of prostate cancer. Nutr. Rev. 2010, 68, 542-555. [CrossRef] [PubMed]

206. Messina, M.J. Emerging evidence on the role of soy in reducing prostate cancer risk. Nutr. Rev. 2003, 61, 117-131. [CrossRef] [PubMed]

207. Sarkar, F.H.; Li, Y.W. Soy isoflavones and cancer prevention. Cancer Investig. 2003, 21, 744-757. [CrossRef]

208. Yan, L.; Spitznagel, E.L. Soy consumption and prostate cancer risk in men: A revisit of a meta-analysis. Am. J. Clin. Nutr. 2009, 89, 1155-1163. [CrossRef] [PubMed]

209. Saxena, A.; Dhillon, V.S.; Shahid, M.; Khalil, H.S.; Rani, M.; Das, T.P.; Hedau, S.; Hussain, A.; Naqvi, R.A.; Deo, S.V.S.; et al. GSTP1 methylation and polymorphism increase the risk of breast cancer and the effects of diet and lifestyle in breast cancer patients. Exp. Ther. Med. 2012, 4, 1097-1103. [PubMed]

210. Frassetto, L.A.; Todd, K.M.; Morris, R.C., Jr.; Sebastian, A. Estimation of net endogenous noncarbonic acid production in humans from diet potassium and protein contents. Am. J. Clin. Nutr. 1998, 68, 576-583. [PubMed]

211. Welbourne, T.C. Acid-base balance and plasma glutamine concentration in man. Eur. J. Appl. Physiol. Occup. Physiol. 1980, 45, 185-188. [CrossRef] [PubMed]

212. Gu, C.; Shi, Y.; Le, G. Effect of dietary protein level and origin on the redox status in the digestive tract of mice. Int. J. Mol. Sci. 2008, 9, 464-475. [CrossRef] [PubMed]

213. Montonen, J.; Boeing, H.; Fritsche, A.; Schleicher, E.; Joost, H.-G.; Schulze, M.B.; Steffen, A.; Pischon, T. Consumption of red meat and whole-grain bread in relation to biomarkers of obesity, inflammation, glucose metabolism and oxidative stress. Eur. J. Nutr. 2013, 52, 337-345. [CrossRef] [PubMed]

214. Wu, G. Amino acids: Metabolism, functions, and nutrition. Amino Acids 2009, 37, 1-17. [CrossRef] [PubMed]

215. De Carvalho, A.M.; de Oliveira, A.A.F.; de Melo Loureiro, A.P.; Gattás, G.J.F.; Fisberg, R.M.; Marchioni, D.M. Arginine intake is associated with oxidative stress in a general population. Nutrition 2017, 33, 211-215. [CrossRef] [PubMed]

216. Ferguson, L.R. Meat and cancer. Meat Sci. 2010, 84, 308-313. [CrossRef] [PubMed]

217. Dodson, S.; Baracos, V.E.; Jatoi, A.; Evans, W.J.; Cella, D.; Dalton, J.T.; Steiner, M.S. Muscle wasting in cancer cachexia: Clinical implications, diagnosis, and emerging treatment strategies. Annu. Rev. Med. 2011, 62, 265-279. [CrossRef] [PubMed]

218. Bernstein, A.M.; Song, M.Y.; Zhang, X.H.; Pan, A.; Wang, M.L.; Fuchs, C.S.; Le, N.; Chan, A.T.; Willett, W.C.; Ogino, S.; et al. Processed and unprocessed red meat and risk of colorectal cancer: Analysis by tumor location and modification by time. PLoS ONE 2015, 10, e0135959. [CrossRef] [PubMed]

219. Anand, S.S.; Hawkes, C.; de Souza, R.J.; Mente, A.; Dehghan, M.; Nugent, R.; Zulyniak, M.A.; Weis, T.; Bernstein, A.M.; Krauss, R.M.; et al. Food consumption and its impact on cardiovascular disease: Importance of solutions focused on the globalized food system: A report from the workshop convened by the world heart federation. J. Am. Coll. Cardiol. 2015, 66, 1590-1614. [CrossRef] [PubMed] 
220. Ollberding, N.J.; Wilkens, L.R.; Henderson, B.E.; Kolonel, L.N.; Le Marchand, L. Meat consumption, heterocyclic amines and colorectal cancer risk: The Multiethnic Cohort Study. Int. J. Cancer 2012, 131, E1125-E1133. [CrossRef] [PubMed]

221. Beresford, S.A.A.; Johnson, K.C.; Ritenbaugh, C.; Lasser, N.L.; Snetselaar, L.G.; Black, H.R.; Anderson, G.L.; Assaf, A.R.; Bassford, T.; Bowen, D.; et al. Low-fat dietary pattern and risk of colorectal cancer-The Women's Health Initiative randomized controlled dietary modification trial. J. Am. Med. Assoc. 2006, 295, 643-654. [CrossRef] [PubMed]

222. Schatzkin, A.; Lanza, E.; Corle, D.; Lance, P.; Iber, F.; Caan, B.; Shike, M.; Weissfeld, J.; Burt, R.; Cooper, M.R.; et al. Lack of effect of a low-fat, high-fiber diet on the recurrence of colorectal adenomas. N. Engl. J. Med. 2000, 342, 1149-1155. [CrossRef] [PubMed]

223. Lanza, E.; Schatzkin, A.; Daston, C.; Corle, D.; Freedman, L.; Ballard-Barbash, R.; Caan, B.; Lance, P.; Marshall, J.; Iber, F.; et al. Implementation of a 4-y, high-fiber, high-fruit-and-vegetable, low-fat dietary intervention: Results of dietary changes in the Polyp Prevention Trial. Am. J. Clin. Nutr. 2001, 74, 387-401. [PubMed]

224. Trapp, D.; Knez, W.; Sinclair, W. Could a vegetarian diet reduce exercise-induced oxidative stress? A review of the literature. J. Sports Sci. 2010, 28, 1261-1268. [CrossRef] [PubMed]

225. Chen, Q.; Espey, M.G.; Sun, A.Y.; Pooput, C.; Kirk, K.L.; Krishna, M.C.; Khosh, D.S.; Drisko, J.; Levine, M. Pharmacologic doses of ascorbate act as a prooxidant and decrease growth of aggressive tumor xenografts in mice. Proc. Natl. Acad. Sci. USA 2008, 105, 11105-11109. [CrossRef] [PubMed]

226. Uetaki, M.; Tabata, S.; Nakasuka, F.; Soga, T.; Tomita, M. Metabolomic alterations in human cancer cells by vitamin C-induced oxidative stress. Sci. Rep. 2015, 5, 13896. [CrossRef] [PubMed]

227. Chen, Q.; Espey, M.G.; Krishna, M.C.; Mitchell, J.B.; Corpe, C.P.; Buettner, G.R.; Shacter, E.; Levine, M. Pharmacologic ascorbic acid concentrations selectively kill cancer cells: Action as a pro-drug to deliver hydrogen peroxide to tissues. Proc. Natl. Acad. Sci. USA 2005, 102, 13604-13609. [CrossRef] [PubMed]

228. Du, J.A.; Martin, S.M.; Levine, M.; Wagner, B.A.; Buettner, G.R.; Wang, S.H.; Taghiyev, A.F.; Du, C.B.; Knudson, C.M.; Cullen, J.J. Mechanisms of ascorbate-induced cytotoxicity in pancreatic cancer. Clin. Cancer Res. 2010, 16, 509-520. [CrossRef] [PubMed]

229. Chen, P.; Yu, J.; Chalmers, B.; Drisko, J.; Yang, J.; Li, B.Y.; Chen, Q. Pharmacological ascorbate induces cytotoxicity in prostate cancer cells through ATP depletion and induction of autophagy. Anti-Cancer Drug 2012, 23, 437-444. [CrossRef] [PubMed]

230. Sharhar, S.; Normah, H.; Fatimah, A.; Fadilah, R.N.; Rohi, G.A.; Amin, I.; Cham, B.G.; Rizal, R.M.; Fairulnizal, M.N. Antioxidant intake and status, and oxidative stress in relation to breast cancer risk: A case-control study. Asian Pac. J. Cancer Prev. 2008, 9, 343-349. [PubMed]

231. Xu, X.; Chen, J. One-carbon metabolism and breast cancer: An epidemiological perspective. J. Genet. Genom. 2009, 36, 203-214. [CrossRef]

232. Lajous, M.; Lazcano-Ponce, E.; Hernandez-Avila, M.; Willett, W.; Romieu, I. Folate, vitamin B-6, and vitamin B-12 intake and the risk of breast cancer among Mexican women. Cancer Epidemiol. Biomark. Prev. 2006, 15, 443-448. [CrossRef] [PubMed]

233. Bassett, J.K.; Severi, G.; Hodge, A.M.; Baglietto, L.; Hopper, J.L.; English, D.R.; Giles, G.G. Dietary intake of B vitamins and methionine and prostate cancer incidence and mortality. Cancer Causes Control 2012, 23, 855-863. [CrossRef] [PubMed]

234. Glauert, H.P.; Calfee-Mason, K.; Stemm, D.N.; Tharappel, J.C.; Spear, B.T. Dietary antioxidants in the prevention of hepatocarcinogenesis: A review. Mol. Nutr. Food Res. 2010, 54, 875-896. [CrossRef] [PubMed]

235. Trottier, G.; Bostrom, P.J.; Lawrentschuk, N.; Fleshner, N.E. Nutraceuticals and prostate cancer prevention: A current review. Nat. Rev. Urol. 2010, 7, 21-30. [CrossRef] [PubMed]

236. Sanchez, G.V.; Weinstein, S.J.; Stolzenberg-Solomon, R.Z. Is dietary fat, vitamin D, or folate associated with pancreatic cancer? Mol. Carcinog. 2012, 51, 119-127. [CrossRef] [PubMed]

237. Johnson, J.; de Mejia, E.G. Dietary factors and pancreatic cancer: The role of food bioactive compounds. Mol. Nutr. Food Res. 2011, 55, 58-73. [CrossRef] [PubMed]

238. Oberley, L.W. Free radicals and diabetes. Free Radic. Biol. Med. 1988, 5, 113-124. [CrossRef]

239. Niedzielska, E.; Smaga, I.; Gawlik, M.; Moniczewski, A.; Stankowicz, P.; Pera, J.; Filip, M. Oxidative Stress in Neurodegenerative Diseases. Mol. Neurobiol. 2016, 53, 4094-4125. [CrossRef] [PubMed] 
240. Sairazi, N.S.M.; Sirajudeen, K.; Asari, M.A.; Mummedy, S.; Muzaimi, M.; Sulaiman, S.A. Effect of tualang honey against KA-induced oxidative stress and neurodegeneration in the cortex of rats. BMC Complement. Altern. Med. 2017, 17, 31.

241. Lindqvist, D.; Dhabhar, F.S.; James, S.J.; Hough, C.M.; Jain, F.A.; Bersani, F.S.; Reus, V.I.; Verhoeven, J.E.; Epel, E.S.; Mahan, L.; et al. Oxidative stress, inflammation and treatment response in major depression. Psychoneuroendocrinology 2017, 76, 197-205. [CrossRef] [PubMed]

242. Kallaur, A.P.; Reiche, E.M.V.; Oliveira, S.R.; Simao, A.N.C.; Pereira, W.L.D.J.; Alfieri, D.F.; Flauzino, T.; Proenca, C.D.; Lozovoy, M.A.B.; Kaimen-Maciel, D.R.; et al. Genetic, immune-inflammatory, and oxidative stress biomarkers as predictors for disability and disease progression in multiple sclerosis. Mol. Neurobiol. 2017, 54, 31-44. [CrossRef] [PubMed]

243. Carrier, A. Metabolic syndrome and oxidative stress: A complex relationship. Antioxid. Redox Signal. 2017, 26, 429-431. [CrossRef] [PubMed]

244. Ratneswaran, A.; Sun, M.M.G.; Dupuis, H.; Sawyez, C.; Borradaile, N.; Beier, F. Nuclear receptors regulate lipid metabolism and oxidative stress markers in chondrocytes. J. Mol. Med. 2017, 95, 431-444. [CrossRef] [PubMed]

245. Doppler, H.; Storz, P. Mitochondrial and Oxidative Stress-Mediated Activation of Protein Kinase D1 and its importance in Pancreatic Cancer. Front. Oncol. 2017, 7, 41. [CrossRef] [PubMed]

246. Weber, J.; Zuehlsdorff, T.; Cole, D.; Di Antonio, M.; Bohndiek, S. An Activatable Contrast Agent for Photoacoustic Imaging to Probe Oxidative Stress in Cancer. Proc. Physiol. Soc. 2016, 36, C06.

247. Piskounova, E.; Agathocleous, M.; Murphy, M.; Hu, Z.P.; DeBerardinis, R.; Morrison, S. Oxidative stress limits metastasis of human melanoma cells. Cancer Res. 2016, 76, 2806. [CrossRef]

248. Toyokuni, S. Oxidative stress as an iceberg in carcinogenesis and cancer biology. Arch. Biochem. Biophys. 2016, 595, 46-49. [CrossRef] [PubMed]

249. Prasad, S.; Gupta, S.C.; Pandey, M.K.; Tyagi, A.K.; Deb, L. Oxidative stress and cancer: Advances and challenges. Oxidative Med. Cell. Longev. 2016, 2016, 5010423. [CrossRef] [PubMed]

250. Gorrini, C.; Harris, I.S.; Mak, T.W. Modulation of oxidative stress as an anticancer strategy. Nat. Rev. Drug Discov. 2013, 12, 931-947. [CrossRef] [PubMed]

251. DeNicola, G.M.; Karreth, F.A.; Humpton, T.J.; Gopinathan, A.; Wei, C.; Frese, K.; Mangal, D.; Yu, K.H.; Yeo, C.J.; Calhoun, E.S.; et al. Oncogene-induced Nrf2 transcription promotes ROS detoxification and tumorigenesis. Nature 2011, 475, 106-109. [CrossRef] [PubMed]

252. Ramos-Gomez, M.; Kwak, M.-K.; Dolan, P.M.; Itoh, K.; Yamamoto, M.; Talalay, P.; Kensler, T.W. Sensitivity to carcinogenesis is increased and chemoprotective efficacy of enzyme inducers is lost in Nrf2 transcription factor-deficient mice. Proc. Natl. Acad. Sci. USA 2001, 98, 3410-3415. [CrossRef] [PubMed]

253. Iida, K.; Itoh, K.; Kumagai, Y.; Oyasu, R.; Hattori, K.; Kawai, K.; Shimazui, T.; Akaza, H.; Yamamoto, M. Nrf2 is essential for the chemopreventive efficacy of oltipraz against urinary bladder carcinogenesis. Cancer Res. 2004, 64, 6424-6431. [CrossRef] [PubMed]

254. Hayes, J.D.; McMahon, M. The double-edged sword of Nrf2: Subversion of redox homeostasis during the evolution of cancer. Mol. Cell 2006, 21, 732-734. [CrossRef] [PubMed]

255. Hu, X.; Roberts, J.R.; Apopa, P.L.; Kan, Y.W.; Ma, Q. Accelerated ovarian failure induced by 4-vinyl cyclohexene diepoxide in Nrf2 null mice. Mol. Cell. Biol. 2006, 26, 940-954. [CrossRef] [PubMed]

256. Xu, C.J.; Yuan, X.L.; Pan, Z.; Shen, G.X.; Kim, J.H.; Yu, S.W.; Khor, T.O.; Li, W.G.; Ma, J.J.; Kong, A.N.T. Mechanism of action of isothiocyanates: The induction of ARE-regulated genes is associated with activation of ERK and JNK and the phosphorylation and nuclear translocation of Nrf2. Mol. Cancer Ther. 2006, 5, 1918-1926. [CrossRef] [PubMed]

257. Ma, Q. Role of Nrf2 in Oxidative Stress and Toxicity. Annu. Rev. Pharmacol. Toxicol. 2013, 53, 401-426. [CrossRef] [PubMed]

258. Satoh, T.; McKercher, S.R.; Lipton, S.A. Nrf2/ARE-mediated antioxidant actions of pro-electrophilic drugs. Free Radic. Biol. Med. 2013, 65, 645-657. [CrossRef] [PubMed]

259. Trachootham, D.; Alexandre, J.; Huang, P. Targeting cancer cells by ROS-mediated mechanisms: A radical therapeutic approach? Nat. Rev. Drug Discov. 2009, 8, 579-591. [CrossRef] [PubMed]

260. Ranjan, P.; Anathy, V.; Burch, P.M.; Weirather, K.; Lambeth, J.D.; Heintz, N.H. Redox-dependent expression of cyclin D1 and cell proliferation by Nox1 in mouse lung epithelial cells. Antioxid. Redox Signal. 2006, 8, 1447-1459. [CrossRef] [PubMed] 
261. Martindale, J.L.; Holbrook, N.J. Cellular response to oxidative stress: Signaling for suicide and survival. J. Cell. Physiol. 2002, 192, 1-15. [CrossRef] [PubMed]

262. Zhao, W.; Lu, M.S.; Zhang, Q.W. Chloride intracellular channel 1 regulates migration and invasion in gastric cancer by triggering the ROS-mediated p38 MAPK signaling pathway. Mol. Med. Rep. 2015, 12, 8041-8047. [CrossRef] [PubMed]

263. Wang, P.; Zeng, Y.; Liu, T.; Zhang, C.; Yu, P.W.; Hao, Y.X.; Luo, H.X.; Liu, G. Chloride intracellular channel 1 regulates colon cancer cell migration and invasion through ROS/ERK pathway. World J. Gastroenterol. 2014, 20, 2071-2078. [CrossRef] [PubMed]

264. Shi, Y.; Nikulenkov, F.; Zawacka-Pankau, J.; Li, H.; Gabdoulline, R.; Xu, J.; Eriksson, S.; Hedström, E.; Issaeva, N.; Kel, A. ROS-dependent activation of JNK converts p53 into an efficient inhibitor of oncogenes leading to robust apoptosis. Cell Death Differ. 2014, 21, 612-623. [CrossRef] [PubMed]

265. Shimura, T.; Sasatani, M.; Kamiya, K.; Kawai, H.; Inaba, Y.; Kunugita, N. Mitochondrial reactive oxygen species perturb AKT/cyclin D1 cell cycle signaling via oxidative inactivation of PP2A in lowdose irradiated human fibroblasts. Oncotarget 2016, 7, 3559-3570. [PubMed]

266. Leslie, N.R.; Bennett, D.; Lindsay, Y.E.; Stewart, H.; Gray, A.; Downes, C.P. Redox regulation of PI 3-kinase signalling via inactivation of PTEN. EMBO J. 2003, 22, 5501-5510. [CrossRef] [PubMed]

267. Xu, D.; Rovira, I.I.; Finkel, T. Oxidants painting the cysteine chapel: Redox regulation of PTPs. Dev. Cell 2002, 2, 251-252. [CrossRef]

268. Sullivan, L.B.; Chandel, N.S. Mitochondrial reactive oxygen species and cancer. Cancer Metab. 2014 , 2, 17. [CrossRef] [PubMed]

269. Harris, I.S.; Blaser, H.; Moreno, J.; Treloar, A.E.; Gorrini, C.; Sasaki, M.; Mason, J.M.; Knobbe, C.B.; Rufini, A.; Halle, M.; et al. PTPN12 promotes resistance to oxidative stress and supports tumorigenesis by regulating FOXO signaling. Oncogene 2014, 33, 1047-1054. [CrossRef] [PubMed]

270. Shi, X.; Zhang, Y.; Zheng, J.; Pan, J. Reactive oxygen species in cancer stem cells. Antioxid. Redox Signal. 2012, 16, 1215-1228. [CrossRef] [PubMed]

271. Diehn, M.; Cho, R.W.; Lobo, N.A.; Kalisky, T.; Dorie, M.J.; Kulp, A.N.; Qian, D.; Lam, J.S.; Ailles, L.E.; Wong, M.; et al. Association of reactive oxygen species levels and radioresistance in cancer stem cells. Nature 2009, 458, 780-783. [CrossRef] [PubMed]

272. Schafer, Z.T.; Grassian, A.R.; Song, L.; Jiang, Z.; Gerhart-Hines, Z.; Irie, H.Y.; Gao, S.; Puigserver, P.; Brugge, J.S. Antioxidant and oncogene rescue of metabolic defects caused by loss of matrix attachment. Nature 2009, 461, 109-113. [CrossRef] [PubMed]

273. Dayem, A.A.; Choi, H.Y.; Kim, J.H.; Cho, S.G. Role of oxidative stress in stem, cancer, and cancer stem cells. Cancers 2010, 2, 859-884. [CrossRef] [PubMed]

(C) 2017 by the authors. Licensee MDPI, Basel, Switzerland. This article is an open access article distributed under the terms and conditions of the Creative Commons Attribution (CC BY) license (http://creativecommons.org/licenses/by/4.0/). 